\title{
Lo uno y lo múltiple: una autoetnografía en un centro para refugiados en el sureste de Italia
}

The One and the Multiple: An Autoethnography at a Refugee Center in Southeast Italy

\section{RESUMEN}

Este texto fue escrito por una estudiante de antropología en 2005, a partir de notas escritas por la misma estudiante, cinco años atrás. Muestra la tensión producida por tener que escribir algo con valor académico para que sea aceptado como antropología, mientras al mismo tiempo se cuestiona la obligación de decir cosas que otros ya hubieran dicho con el fin de que fueran aceptadas como válidas. A partir de mi experiencia como voluntaria, en el año 2000, en un centro para refugiados en el sureste de Italia, tomo como excusa la multiculturalidad, el encuentro de diferentes culturas en un mismo espacio, usando la autoetnografía y también el concepto de lo uno y lo múltiple.

Palabras clave: autoetnografía, "lo uno y lo múltiple", multiculturalidad.

\section{Abstract}

This text was written by an anthropology student in 2005 , based on notes written by the student herself five years earlier. It shows the stress produced by the requirement to write something with academic value to be accepted as anthropology, while at the same time, the obligation to say things that others have already said in order to be accepted as valid is questioned. From my experience as a volunteer in

\author{
Aída lucía Sánchez-Pérez \\ Antropóloga, Especialista \\ en Estudios del Caribe \\ Autoridad Nacional de \\ Licencias Ambientales, \\ Bogotá, Colombia. \\ 凹aidalucia@yahoo.com \\ (1D) ORCID: 0000-0003-4241-7376 \\ $\checkmark$ Google Scholar
}


a center for refugees in the southeast of Italy in 2000, I take multiculturalism, the encounter of different cultures in the same space as an excuse using autoethnography and also the concept of the one and the multiple.

Keywords: autoethnography, "the one and the multiple", multiculturalism.

\section{Introducción}

n el año 2005, muchos estudiantes tuvimos que graduarnos para
que no nos echaran de la Universidad Nacional de Colombia.
Fuimos muchos los que tuvimos que buscar urgentemente un tema para hacer una monografía y optar por un título de pregrado, renunciando a nuestra cómoda calidad de estudiantes. Es que hay que ser alguien en la vida, y para eso ayuda mucho un título.

En ese momento, nueve años después de haber empezado a estudiar antropología, mi problema de investigación era que debía tener un problema de investigación. Era un problema porque yo lo que sentía era que la única forma posible de hacer antropología era desde mí misma, y en ese momento no sabía que existiera algo que se llamara "autoetnografía".

Tenía otro problema, y es que sentía que "yo" no existía, porque "yo" era el todo; todo el universo, y el "todo" era yo misma. Entonces, tenía también el problema de tener que escribir desde algo que no existía.

Decidí entonces tomar mi experiencia como voluntaria, en el año 2000, en un centro para refugiados en el sureste de Italia, para producir un texto académico que me permitiera cumplir con el requisito para obtener el preciado título. La excusa era la multiculturalidad, el encuentro de diferentes culturas en un mismo espacio, usando la autoetnografía, que poco tiempo después me enteré de que existía, y también el concepto de "lo uno y lo múltiple", que también me enteré después de que otros habían escrito sobre eso. Y como necesitaba tener validez académica para que mi director de la monografía y los jurados me dejaran graduar, en ese momento me servía encontrar que otros antes hubieran dicho lo que yo unos años atrás había pensado.

Este texto es una parte de esa monografía, que finalmente me permitió tener un título de antropóloga. Veinte años después, sigo sin 
saber si soy alguien en la vida. Veinte años después sigo sintiendo que no puedo sino escribir a través de mí, y que no soy yo la que escribe.

\section{La manera como empiezo}

Podría empezar por un principio introductorio, que supusiera mi labor como antropóloga que va a hablar del tema de los refugiados en el sureste de Italia, al menos parcialmente distanciada de lo que está siendo su vida en este momento. Podría, pero no. No puedo. Podría solo si no fuera yo. No es fácil escribir esto sentada frente al computador, intentando producir un texto que se me pide (o que yo me pido) como requisito para optar al título de antropóloga, cuando mi hermano está viviendo episodios bastante conocidos, vividos y sufridos por mí; episodios de algo que si alguien quisiera nombrar seguramente lo llamaría "locura". No es fácil escribir esto cuando pienso, con gran preocupación, en la salud mental de mi hermano y, de paso, también en la mía.

Ese estado de conciencia permanente e inevitable, de pensar en no querer pensar más, de sentirme sin poderme sentir, de miles de contradicciones que no se contradicen, de encontrarme mientras me alejaba cada vez más de mí misma, de pasar de ser una infinitamente pequeña parte de todo el universo a ser todo el universo yo misma, de muchas otras sensaciones que hubiera querido en ese momento que se debieran al consumo de alguna sustancia alucinógena, me llevó a replantearme, entre muchas otras cosas, la antropología; cada vez entendiéndola menos y cada vez encontrándole más sentido; cada vez más metida dentro de ella y ella dentro de mí.

Y ese estar dentro de la antropología sin poder escapármele por más intentos que hiciera me llevó también, junto con otras más cosas que terminan y empiezan siendo la misma cosa, a seguir con mis estudios de antropología en la Universidad Nacional de Colombia después de haberlos dejado por cinco semestres; me llevó a seguir con los estudios asumiéndolos de otra manera, asumiéndolos de la única manera que encontré posible en ese momento, que es el mismo momento en el que estoy sentada escribiendo. Esa única manera posible de seguir con la antropología es partir de mí misma, lo que después supe que es la base de lo que otros ya conocían como autoetnografía. Pero "mí misma" son también todos, todos los otros y los mismos, y eso es lo que, para mí, le podría dar algo de validez a cualquier cosa que tuviera que ver con antropología. Ese pensamiento sobre la antropología me llevó a arriesgarme, arriesgarme a ser y a hacer antropología con la única herramienta posible: la autoetnografía. 


\section{De quiénes y a partir de quiénes escribo}

Podría decir que el objetivo de este trabajo es el de identificar, describir y analizar el tejido de relaciones e interacciones que se producían entre los miembros de la Casa Regina Pacis: un centro de acogida para inmigrantes ilegales en la localidad de San Foca di Melendugno, en la provincia de Lecce, en el sureste de Italia, teniendo en cuenta que provenían de diferentes países de Asia, África, Latinoamérica y Europa Oriental, y que sus motivos para migrar divergían en gran manera entre sí, en función de su edad, género, su país de origen y sus aspiraciones personales particulares. Estos inmigrantes permanecían en la Casa Regina Pacis mientras se resolvía su situación legal en Italia, normalmente después de ser capturados por la policía al desembarcar ilegalmente en las costas italianas. Podría decir que ese es el objetivo de mi trabajo, pero no estoy segura; no estoy segura de si el tema de los refugiados sea solo una excusa. Tampoco estoy segura de si deba ser sincera en cuanto a que no sé todavía cuáles son los objetivos de este trabajo.

Tampoco estoy segura de si deba decir que este es un trabajo poco pretensioso; poco pretensioso y tal vez demasiado pretensioso: pretende ser considerado un trabajo antropológico. A la vez, no pretende decir nada nuevo acerca de la antropología, y para ser todavía más sincera, acerca de nada. Pretende decir que no está diciendo nada, y que la que escribe no es la que escribe; la que escribe pretende estar siendo antropología mientras escribe: siendo y viviendo antropología. ¿Cómo no ser contradictoria si no soy yo, sino todos, los que hablamos mientras yo escribo? Este problema entre lo uno y lo múltiple pretende ser tratado sin citar autores que ya han hablado de eso, que los hay varios; pretende evidenciarlo en su misma escritura.

El trabajo de campo para este escrito lo hice sin pretender hacerlo. Hice un intercambio cultural en Italia de 1999 a 2000, para el cual tenía que hacer un trabajo social y me asignaron la Casa Regina Pacis. Allá llegaba gente de muchas partes del mundo; pero no del primero ni del segundo; llegaba gente del tercero, del cuarto, del quinto y también del sexto mundo. Allá llegaban ellos y allá llegué yo también. Mis labores como voluntaria eran: servir la comida, ayudar con el aseo de la cocina, encargarme de controlar en una lista las personas que comían (para que nadie repitiera), ayudar a los niños a llevar su comida hasta las mesas; en general estar pendiente de lo que fuera necesario a la hora de comer. Además, daba clases de italiano a los refugiados y a veces ayudaba en actividades recreativas con los niños, como hacer juegos o llevarlos a la playa que quedaba en frente del Centro. 
Tenía la oportunidad de tener contacto cercano con los refugiados; algunos trabajaban conmigo en la cocina haciendo las mismas labores que yo. Y durante el tiempo que no estaba trabajando, me quedaba en Regina Pacis compartiendo con ellos; hablando con los que podía, y también con los que no; jugando con los niños, ayudándoles en lo que pudiera o dejándome ayudar por ellos. Como el centro se encontraba en un lugar aislado, la ciudad más cercana era a 30 kilómetros y no había transporte público, yo pasaba casi todo mi tiempo libre con ellos.

Todos llegamos allí por motivos diferentes; unos pidiendo asilo político, otras detenidas por prostitución, otros por arresto domiciliario, otros por trastornos mentales, otros como voluntarios; pero todos éramos lo mismo.

De ese modo, no quedaba otra cosa que vivir. Vivir con ellos mientras se resolvía su situación legal, compartir mi vida con ellos, mis compañeros temporales de ese espacio que se me era dado, tratando inútilmente de dejar de lado la inevitable y casi siempre desagradable sensación de poder "usar" esa vivencia como un conocimiento con validez antropológica. Digo desagradable porque ese pensamiento atemporal, me impedía cumplir mi real y único objetivo: vivir la inmediatez del presente.

Decidí entonces apropiar una forma de vida que me permitiera ser antropóloga para vivir y no lo contrario: aprovechar los conceptos y herramientas adquiridos durante mis cinco semestres de carrera para la consecución de mi objetivo. No caer en la falacia de vivir todas estas cosas para después llegar, escribirlas ordenadamente y presentarlas a alguien esperando su aprobación. Allí no había nada que aprobar.

Ahora que tengo como requisito escoger un tema para hacer una tesis de grado en antropología, se me viene a la mente este como experiencia antropológica concreta, porque atractivamente antropológica puede ser una casa. Una casa en la que vive gente de todos los colores, no de todos los colores de piel, aunque también. Las relaciones, las interacciones que se producen entre personas de diferentes países, de diferentes mundos, colores, olores y sabores. Musulmanes de Asia, musulmanes de África, católicos del Medio Oriente, de América del Sur, del Oriente Medio y del oriente de Europa; gente del cercano y del lejano oriente, del lejano occidente, del que en esa casa todos eran cercanos. Todos bajo el mismo techo. Antropológicamente interesante puede ser, y muchos han hablado de eso, muchos que me han recomendado leer, que han hablado de conceptos como las interacciones, las nuevas dinámicas sociales, la globalización, las identidades transeúntes, y más 
conceptos que no tengo; no son míos ni me los he apropiado, no los he tomado prestados; pero si en realidad no lo hiciera, ni siquiera podría estar escribiendo en esta lengua del lejano occidente. De una cosa creo estar segura, y es de que, si no hubiera pasado varios semestres en la carrera de antropología de la Universidad Nacional de Colombia, no podría estar escribiendo esto que ahora escribo y que ya escribí. Mientras vivía con los refugiados escribía, y cuando escribía lo que escribía, recordaba mis clases desde primer semestre; las recordaba y a algunas les encontraba sentido. No estoy pretendiendo descalificar a la academia, porque no estaría escribiendo esto si no hubiera estudiado antropología, pero también si no hubiera vivido lo que viví con todas y cada una de las personas con las que viví y que también soy. Entre esas, obviamente, también están los refugiados en los que yo ahora me refugio.

No sé si el haber hecho el trabajo de campo hace cinco años en un sitio tan geográficamente lejano sea una dificultad. Tampoco sé si el haber escrito todo lo que escribí sin ninguna pretensión de carácter académico sea una dificultad o más bien una ventaja.

\section{Escribiendo y mirando por la ventana}

No podría, como lo hiciera en su tiempo el señor Bronislaw Malinowsky, tener por separado mi diario personal de mi diario de campo. Me queda incluso difícil separar lo que otros dicen de lo que yo digo. Es que todos somos uno, una sola cosa.

Yo empecé a escribir esto desde hace mucho, más de cinco años, y quiero poner acá algo de lo que en esa época escribía, que para mí tiene todo que ver con el tema de este escrito.
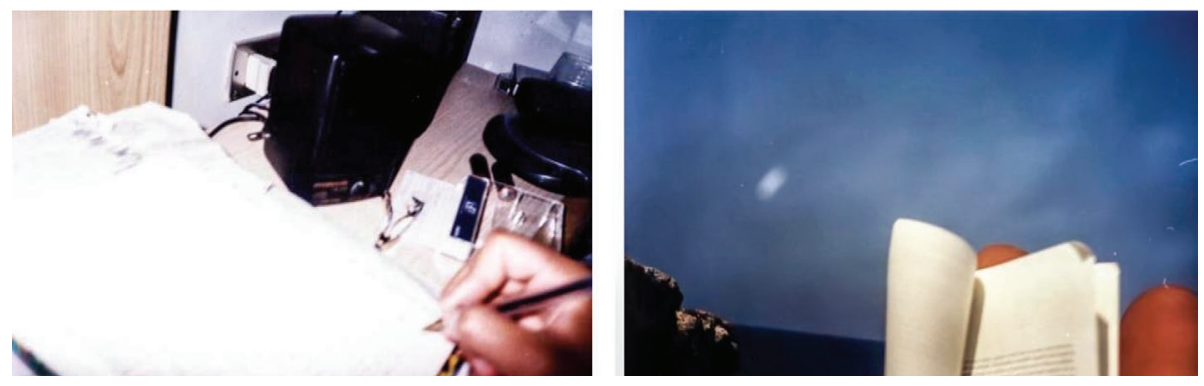

Fotos 1 y 2. Escribiendo y leyendo; leyendo y escribiendo, para mí eran la misma cosa.

Esta mano que escribe dejará de funcionar. Mi cerebro será comida de gusanos. O de animales de mar. O cenizas. Mi ropa se convertirá en 
trapos viejos que otros excavarán en el futuro para entender el pasado, para escribir el pasado, y también para leerlo. Estoy siendo pasado ahora que escribo.

Era el nuevo milenio; se suponía que todo estaba cambiando. Yo estaba en Barcelona, donde también estaba El Hombre del Milenio: una estructura metálica de 15 metros que cobró vida con la llegada de los primeros segundos del 2000; un montaje tecno-mitológico creado por un grupo teatral, que se iluminó con la llegada del nuevo milenio, mientras una campana marcaba el ritmo de las uvas y, en el suelo, la plaza de Catalunya se convirtió en un inmenso reloj digital.

Estábamos El Hombre del Milenio, yo, y mucha gente más en la Plaza Catalunya. También estaba la hermosa alemana que me decía que me emborrachara porque se iba a acabar el milenio. Tenía ojos muy bonitos y también la cara. Era un tiempo para celebrar. Toda esa gente que estaba conmigo en la plaza Catalunya ya no es la misma, ahora que la escribo. Ya no es la misma gente porque en ese momento yo no pensaba esto, ni cuando escribí estas notas de campo que ahora transcribo y que eran cualquier cosa menos notas de campo. En ese momento era otra cosa, pero ahora lo vuelvo a vivir. Lo tengo acá en mis manos, en ese momento era tinta, ahora es teclado de computador. Era el nuevo milenio y se suponía que algo nuevo estaba empezando, pero ahí solo había gente, la mayoría borracha, que iba a seguir borracha con la llegada del nuevo milenio.

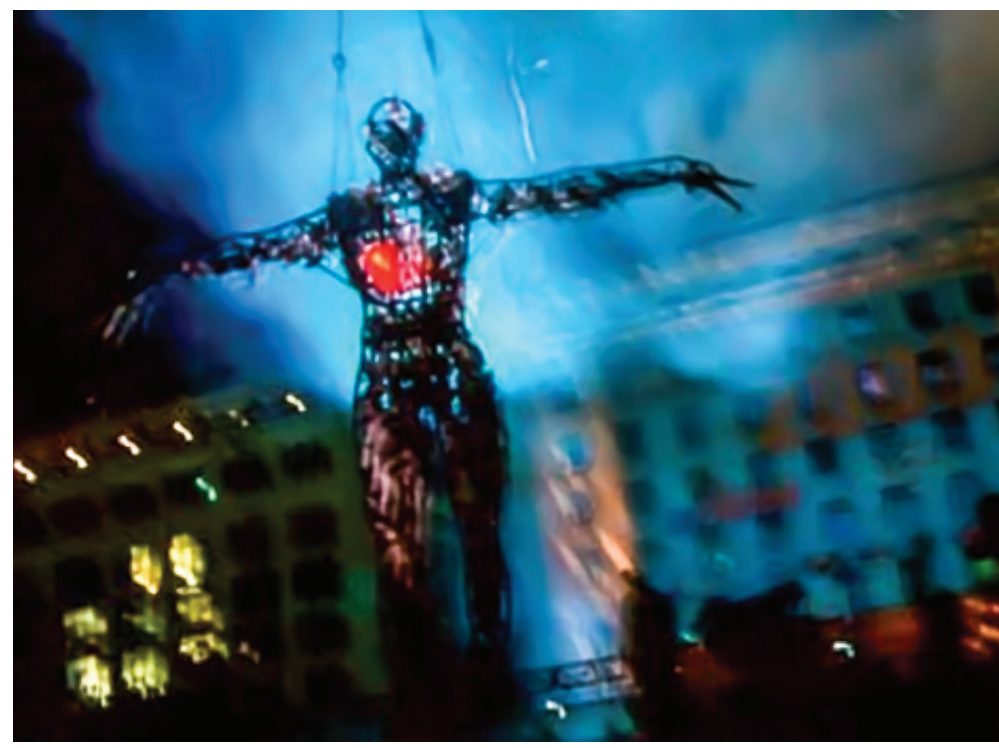

Foto 3. El Hombre del Milenio en Barcelona. 
Ese momento ya se fue. Ya no existe. No existe, pero existirá siempre. No existe porque existirá siempre. No existe, aunque existirá siempre. Seguía escribiendo solo porque el esfero escribía rico en ese cuaderno que me regalaron. Si no, tal vez no escribiría. No lo escribiría acá pero ya lo había escrito. No hay nada nuevo que decir; yo no estaba escribiendo nada, solo la vida que era una metáfora. Esta vida era muerte; una muerte que no existía, porque nada se muere. Nada nace. Era una transformación de la misma cosa. De la nada. Y del todo.

¿Era energía? La energía no se crea ni se destruye; solo se transforma. Esto lo aprendí en el colegio. Lo aprendí y lo olvidé. Aprender es olvidar. Y si simplemente somos transformación de una cosa que llaman energía, ¿qué sentido tiene estar sentada escribiendo esto, transformando mis pensamientos que no son míos en letras negras de computador? Aunque por mucho tiempo me dio miedo, ahora retomo a Borges y su Biblioteca de Babel: "La certidumbre de que todo está escrito nos anula o nos afantasma". Lo cito porque él es un escritor. Y yo solo estoy esperando una aprobación para graduarme de antropóloga, aunque desde hace bastante tiempo considero la posibilidad de que este escrito no sirva para nada académicamente hablando; que no cumpla con los requisitos que impone la academia, la institución universitaria que se nos ha legado, como tantas otras cosas del Viejo Continente que es igual de viejo que este, y que es el mismo; le creo a mis profesores de geografía, les creo que esto era una Pangea y que hace muchos, muchos años, estábamos unidos. Para mí todavía lo seguimos estando, seguimos siendo la misma cosa.

Pero no sé si voy a poder ser antropóloga; no sé si estoy preparada para "contribuir al estudio y entendimiento de la diversidad socio-cultural, histórica y biológica de las distintas poblaciones colombianas, y su rescate para el desarrollo integral del pais; profundizar en los paradigmas, las temáticas y los problemas que constituyen el panorama más significativo de la disciplina a nivel mundial, sus desarrollos y tendencias; realizar investigaciones básicas y aplicadas en los campos de la Antropología Socio-Cultural, Etnohistoria, Arqueología y Antropología Biológica, utilizando métodos actualizados; participar en el diseño, planeación y evaluación de programas de desarrollo social, cultural, histórico y biológico; contribuir al análisis de la problemática étnica nacional y en las estrategias de solución a ella, participar en investigaciones interdisciplinarias en diversos campos de la problemática nacional, tales como el conflicto, salud, educación, vivienda, familia, género; planear, dirigir y ejecutar programas de documentación, conservación, clasificación y análisis de materiales arqueológicos y museográficos; contribuir al conocimiento de la diversidad biológica de las poblaciones colombianas para su aplicación en los campos 
de la salud, ergonomía e identificación humana"1. No sé si yo sea capaz de todo eso, pero esos son los objetivos del programa curricular de la carrera que escogí un día, a los 17 años, sin tener ni idea de qué era la antropología.

Y entonces, como decía, si mi experiencia en el campo de refugiados en Italia no me sirve para hacer una tesis de antropología que cumpla con los requisitos, creo que no va a haber nada que lo haga, que me sirva para la antropología; entonces por lo menos tendré la esperanza de que mi permanencia en Italia me sirva para dar clases de italiano, que ya lo he hecho y hasta de pronto gano más plata que como antropóloga. O tal vez me dedique a dar clases de nado sincronizado; que de algo me sirvan los duros entrenamientos en la Liga del Valle del Cauca, eso sí que da mucha más plata que la antropología. O también puedo dedicarme a vender ropa, y aunque todas estas cosas ya las hago, algo hace que siga intentándolo por este lado. Algo me lo dice; tal vez han sido unos pocos profesores del departamento de antropología. También he considerado la posibilidad de estudiar otra carrera; alguna ingeniería, arquitectura, economía, o algo de lo que pueda vivir y que no me haga enfrentarme tan crudamente con la nada, con la locura que ya experimenté en carne propia, que es la que me hace escribir esto que escribo, la que me ha hecho seguir formalmente con la antropología, y que, sobre todo, tanto me ha hecho sufrir. Desafortunada o afortunadamente, no concibo la antropología sin relacionarla con mis episodios psicóticos, otra razón para estar buscando una alternativa por si no me puedo graduar como antropóloga de la Universidad Nacional de Colombia.

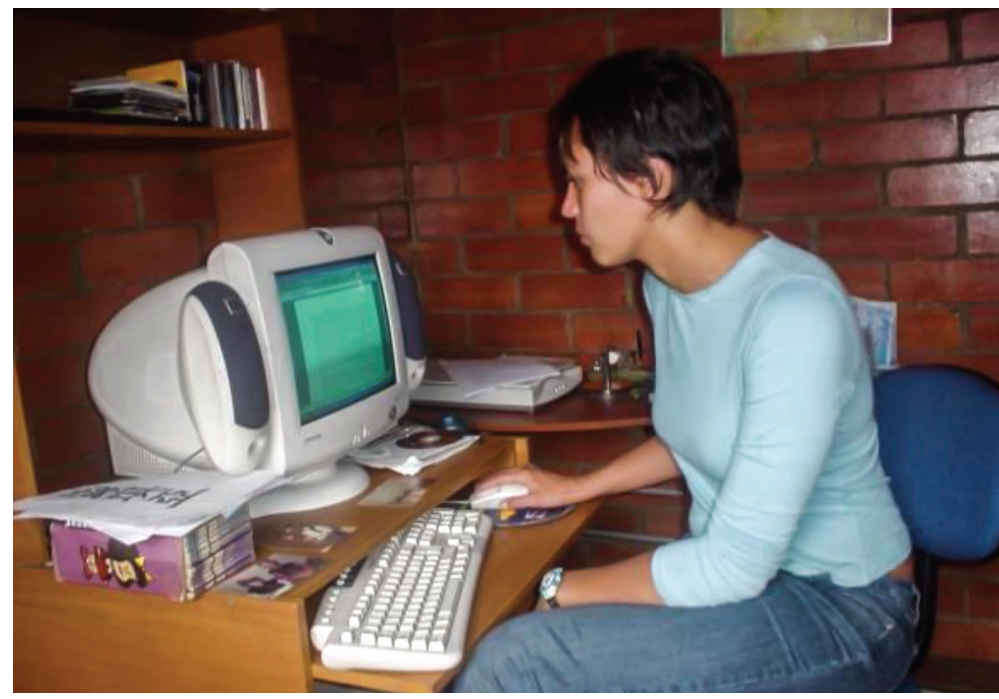

Foto 4. Ahora. Y también después cuando eso sea leído. 
Paso de mis notas de campo de hace cinco años a lo que escribo ahora que estoy haciendo la monografía, intento tener un orden, una coherencia, pero eso también se contradice con lo que digo. No tengo pensado hacer capítulos. Tampoco citar bibliografía; todo el tiempo lo estoy haciendo porque no soy yo la que escribe, somos todos. Tengo varios archivos de Microsoft Word abiertos y en todos escribo en desorden, en el único orden posible, en el mío. Yo solo escribo viviendo el presente, este eterno presente de letras negras de computador; escribo transformando el presente en pasado y futuro que no son sino este presente que soy yo.

Antes de mencionar a Borges, estaba transcribiendo mis notas de campo, que eran cualquier cosa menos eso. Y me fui por otros lados, por eso este texto está tan desordenado que no sé si logre ordenarlo, aunque el orden no exista porque finalmente todo es la misma cosa. Para mi fortuna y a veces también para mi desgracia, no puedo dejar de estar conmigo.

El fin de milenio en Barcelona, donde algo nuevo estaba comenzando - ¿y algo estaba terminando?-, nunca se me olvidará. Yo no olvido. Esta es mi vida. Una película. Una película tonta. Una película de terror, de suspenso, una película triste, cómica. Esto es mi vida que no es mía. La película que hacen otros. Que ven otros con los ojos de afuera. Porque los míos solo ven para afuera; tratan de ver para adentro, pero no se puede. Porque así es la fisiología humana. Esto me hace pensar en una lectura de primer semestre, "El lente antropológico", que no me acuerdo quién escribió, ni qué decía, pero esto que digo me recuerda ese título.

Ahora, mientras escribo escucho ópera, que también me trae recuerdos de Barcelona, del fin del milenio y del viaje y los refugiados y la antropología y la historia. Escribo con ganas, pero me dan ganas también de tocar piano. Y paro. Y después seguiré y los lectores ni se darán cuenta. Y no importará. Pero sí. Me pongo a tocar la sonata Claro de luna, de Beethoven, a la que Ludwig ni siquiera le puso ese nombre. Pero ¿evoca un claro de luna? A mucha gente de pronto sí. Pero tal vez si saben que no fue Beethoven el que le puso ese nombre se los deja de evocar. Al menos a mí me pasó. Cómo es de débil la mente humana; cómo es de débil mi mente humana. Beethoven, como todos, también escribe conmigo. 


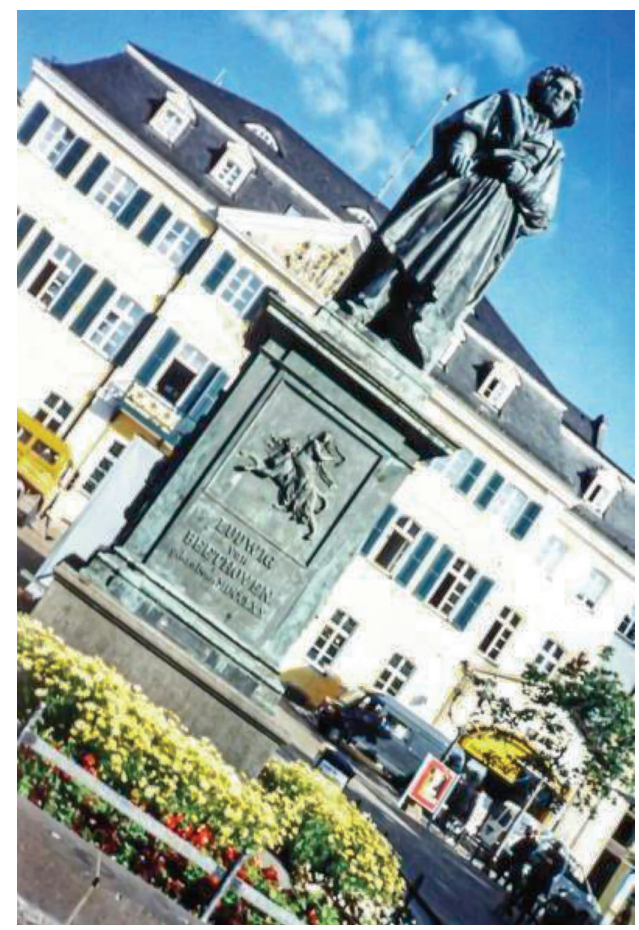

Foto 5. En Bonn con Ludwig.

¿Tengo que escribir todo? Acá en Italia es invierno, el invierno del 2000. Y es por la mañana, aunque ahora que lo escribo sea por la tarde. Esta mañana del cielo blanco y los árboles sin hojas. Son las siete y media de la mañana y está oscuro; está oscuro en este invierno blanco. Ayer nevó. Esta mañana era fría. El blanco azul y gris del cielo eran una sola cosa. Este paisaje blanco de árboles sin hojas, en donde no se veían claros los límites entre los árboles y el cielo por la niebla, era frío. Pero no importaba, yo iba en el bus caliente que me llevaba. Yo no tenía hambre. No tengo hambre. Mi cerebro trataba de ver para adentro y no veía nada. ¿Acaso el cerebro podía ver? Todo ya estaba escrito. Yo tenía la testa vacía. La testa vuota. Tenía la cabeza vacía.

Yo no quería escribir nada, yo lo quería vivir, como lo estaba haciendo, como lo haría siempre, como lo seguiría haciendo eternamente, aunque no quisiera. Nadie había pedido nacer. Nadie lo pidió. Y aquí estábamos todos bajo las manos de quién sabe qué cosa extraña. Bajo las manos de todos, las manos mías. Eran las manos nuestras; la mano de nadie la que nos manejaba. El tipo del frente tiene cara de español. Me recuerda mi viaje a Barcelona. ¿Luego voy a editar todo esto?, ¿por qué?, ¿por qué no? La eternidad de la pregunta. La eternidad de la respuesta. Un para qué lleva a otro para qué. No lo decía yo. 
Me lo decía el profesor Guillermo Páramo Rocha, un día que me tomé un tinto con él, cuando lo busqué para usarlo como psiquiatra y él me hizo sentir que no estaba loca. Un tinto. ¿Para qué la taza? Para tomar ¿Y para qué? Era la eternidad de la pregunta.

Una cosa se me viene a la mente: el aburrimiento del que lee. No lo había pensado. El que esté leyendo esto, si es que alguien lo lee, se puede aburrir. Es siempre lo mismo. Es una historia sin ilación. Nadie va a entender. ¿Y si la hago con ilación?, ¿para que entienda quién?, ¿los jurados de la Carrera antropología de la Universidad Nacional de Colombia?, ¿para que entiendan qué?, ¿es que acaso hay algo que entender? Es difícil ser consecuente. Pero no tengo que serlo, porque es que no soy yo la que escribe. Pero no descarto que alguien se aburra o se desespere por no estar yo diciendo algo.

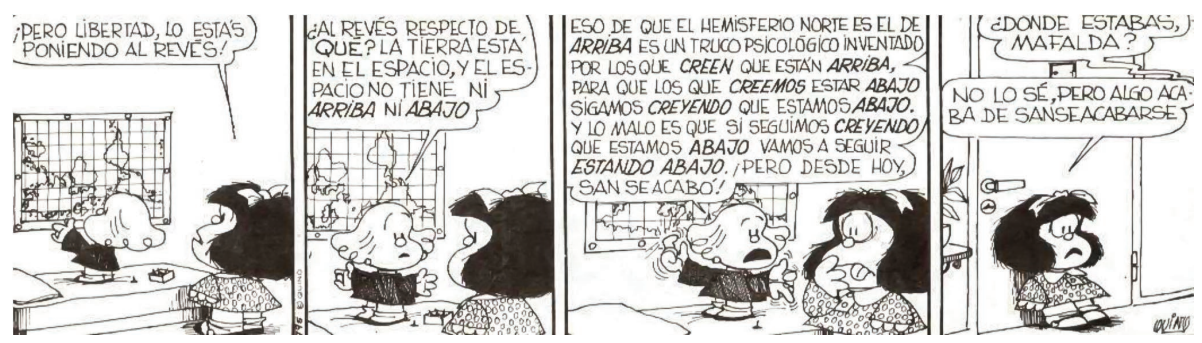

Foto 6. Mafalda.

Lo que digo suena repetitivo, aburrido, pretensioso y algunas veces ha sonado también agresivo. A mí a veces tampoco me gusta lo que digo; no soy solo una. Yo ni siquiera sé si esto pretenda ser antropológico.

Tal vez haya cosas que decir; que el tiempo no existe, que el yo no existe sin el otro, que estamos, pero no estamos. En todo eso pienso y también en mis clases de antropología, desde primer semestre. Recuerdo por ejemplo el difusionismo cultural; era inevitable pensar en él cuando vivía en una casa donde había gente de todas partes y yo lo veía, lo sentía, lo olía, lo experimentaba en carne propia. Todo el tiempo lo hago; estamos en constante difusión. En constante transformación, también la antropología. Pero el vivir con refugiados hizo más evidente lo que ya era evidente para mí. Que todos somos lo mismo, todos y todo, incluso el tiempo. Y también el espacio. Todos somos lo mismo pero cada uno solo; yo estoy sola en mi soledad de escritora que puede que a nadie le interese.

Yo podría armar una historia de cualquier cosa. ¿Por qué no hacer varios libros? Si nadie más los lee no importa; yo ya lo estaba escribiendo. 
Este libro me lo estaba disfrutando. Y a la vez era una humillación. Era la misma humillación del hombre de las ruinas circulares (otra vez Borges) que descubrió que era un sueño soñado por otro. Era la misma, pero ya era otro sueño.

Miro por la ventana. El cielo azul, las montañas nevadas. La señora jugando Tetris me acuerda de mi mamá, que se pasaba las horas así. Yo tengo tiempo para perder. Yo no hago nada, como dice Maria la cuoca. María la cocinera. Ella tiene que venir todos los días a cocinar. Todos los días la misma rutina. Es su destino. Pero le piace molto. Le gusta mucho. Es feliz cocinando. Ella nació para ser cuoca. Así como otros nacieron para ser ingenieros, o pintores, o médicos o escritores. Y Lucía, Aída Lucía Sánchez Pérez, ¿para qué habrá nacido? Parece no ser suficiente haber nacido para estar viva.

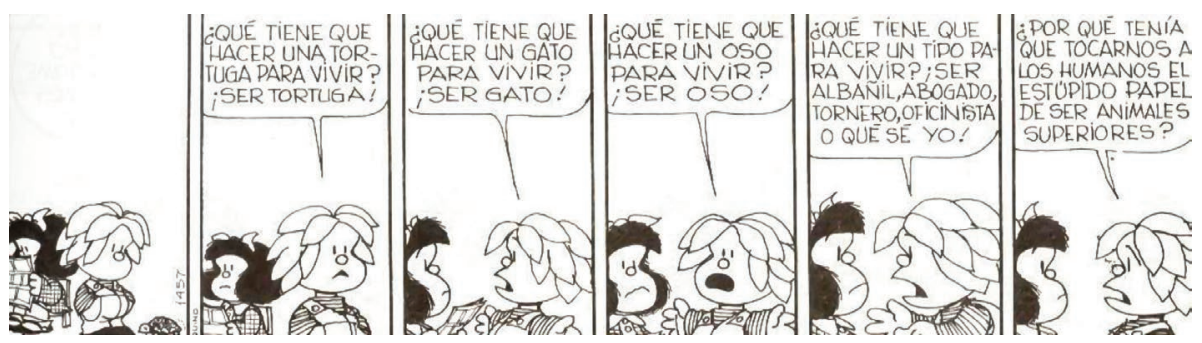

Foto 7. Mafalda.

Superiores somos porque somos nosotros los que lo decimos. Pero somos iguales que los perros, las tortugas, las hormigas. Iguales a los otros animales con su ingenio, sus sufrimientos, sus impresionantes formas de organizarse y de comunicarse.

Son tantas cosas que tengo escritas que son todas la misma, entonces no tiene sentido escribirlas todas, si todo ya está escrito. Además, ¿acaso yo puedo ser tan importante? Yo solo estoy sentada en un tren escribiendo. Sólo estoy en un tren viviendo. Cambiando el futuro y el pasado sin cambiar nada. Jugando con el tiempo y el espacio, sabiendo que soy un juego del tiempo y el espacio. Jugando con mi mente que era lo único que existía, aunque yo no la pudiera ver. Aunque yo no la podía ver. Y no la voy a poder ver nunca. Ni oler, ni tocar, ni sentir. No me sabe a nada. Pero si no fuera mi mente lo único que existe, ¿estaría acá sentada escribiendo esto, ahora que no estoy en el tren sino en mi casa en Bogotá, esperando sacar de esto una tesis de grado? No estarían tampoco ustedes leyendo esto en este momento. Y todo sería distinto y nada cambiaría. 
Perdí el hilo de mi diario. De los días uno por uno. Yo había decidido hacerlo así para no enloquecerme. Tal vez luego sería más fácil de leer. Pero ¿cómo era más fácil de escribir? ¿Cómo era más fácil de vivir? Yo de todas maneras lo estaba viviendo.

Entonces decido seguir poniendo a trabajar mi cerebro. Ya dejé la tonta idea de que todos somos máquinas manejadas por una sola cosa. ¿Es tonta? Al menos no es un cerebro humano el que nos maneja, si es que hay algo que nos maneja. ¿Esto era ser humano?, ¿y antes?, ¿y después?

Voy en otro tren y veo el sol por la ventana. Los árboles se mueven. Se mueve el tren. Me muevo yo. El sol está quieto. Yo solo estoy mirando desde una ventana. A veces el sol se mueve. A veces no. Yo veo el movimiento, pero el sol está quieto, escondido entre las nubes. Entre las nubes grises y blancas que son el cielo. Escondido y pequeño, el sol es más pequeño que yo. Me cabe entre los dedos. Es un pequeño círculo que me da luz para escribir. Para escribir y para vivir, que son la misma cosa. Siempre estoy escribiendo, Ahora mientras escribo es de día, está el sol. En el otro lado es de noche. Para mi mamá es de noche.

Y ¿cuál es el norte? Ahora recuerdo la conversación con Alberto en San José de Isnos acerca de cuál era el norte. Cuál es el arriba. Si es que esto es un círculo. Un círculo que no es circular, sino que es eterno.

Ahora voy en otro tren con la preocupación de llegar antes de que se vaya el último bus que me lleva a mi pueblo, Perosa Argentina, mi pueblo, otro lugar en el que viví en Italia. Después de haber estado en Milano con Leonardo Da Vinci y en Pisa con Galileo y tocando el piano del museo de Da Vinci con Beethoven, dependo del chofer para llegar a tiempo y me preocupo. ¿Por qué, si el tiempo no existe? Ahora mientras escribo esto, después de cinco años de haberlo escrito, tampoco existe ese tiempo ni ninguno, ni el tiempo de los relojes ni el de los inganos de Bogotá. Solo el mío. Mientras escribo esto escucho a los Beatles que me recuerdan a Pier Paolo Montà, el mismo que tiene síndrome de Down, que me enseñó tantas cosas de la vida, pero eso es parte de otra historia, de mi historia como voluntaria en un centro para discapacitados que para muchas cosas estaban más capacitados mentalmente que yo y que muchos que conozco y que no conozco. Se supone que esto es sobre mi trabajo como voluntaria en el centro de inmigrantes y prófugos de guerra en el sureste de Italia. 
Pero íbamos en ese tren, iba yo y ahora los que leen esto. Es estúpido ir preocupada, después de todo el día de hoy en Milano, pero acá voy, con Da Vinci, Beethoven, Bach, Goethe, y todos esos. Voy con Diego, Sandra Marlen, la mona. Voy con Camila y con el gordis, que ahora también es antropólogo. Voy con los que menciono y con los que no menciono. Pero estoy sola. Estoy sentada sola, viendo árboles. Viendo que no voy a llegar a tiempo a Pinerolo para alcanzar el otro bus.

Y finalmente me dejó el último bus. Estaba haciendo mucho frío para dormir en la estación de trenes. O en un parque. Pero me tocó, me tocó pasar la noche en el Parque Garibaldi de Pinerolo. Mientras esperaba no tenía mucho más que hacer que mirar el cielo. Y verme ahí. Y en esas pasó una estrella fugaz. Tan fugaz como la estrella que pasó una noche mientras esperaba en el parque Garibaldi a que amaneciera para coger el primer bus a mi pueblo. Yo miraba hacia abajo buscándola como tonta. ¿Cómo la iba a ver?, ¿no ve que era fugaz? Era tan eterna que ahora está acá en mi mano. Todavía la veo pasar por entre los árboles en el cielo que no era cielo. Me quedé lo que quedaba de esa noche mirando el cielo. Mirando mis ojos y su circularidad. Mis ojos eran un círculo. Jugué a armar constelaciones. A armar nada. A soñar a unir las estrellas con líneas imaginarias. Con líneas tan reales como estas que yo escribo. Jugué a desbaratar las Osas (la mayor y la menor). Jugué a volverlas a armar. Tenía frío. En este viejo continente que para mí era más nuevo porque lo conocí después, era invierno.

Quiero dar orden a esto. Siento que no existo y quiero engañarme. Todo es mentira, pero también la mentira. Quiero escribir en orden esto; hacer como el profesor Carlos Sánchez con la arqueología y seguir con este engaño. Y que me perdone si lee esto y no se acuerda, pero una vez lo dijo en San José de Isnos. Lo más seguro es que no lo lea, porque él es arqueólogo, y ni siquiera se acordará de mí. Entonces no tendré que disculparme, porque todo esto que escribo a veces no pareciera más que una eterna disculpa. Una eterna justificación. ¿A quién le tengo que justificar que estoy viva? Es como si las tesis de grado no fueran más que pedir permiso a los jurados que las leen. Eso es justamente lo que estoy haciendo, porque también le quiero dar esa tranquilidad a mi mamá y hasta de pronto me tomo una foto en la universidad el día del grado, para que quede de recuerdo, como las fotos que aquí pongo y que seguramente para casi nadie significan algo. 


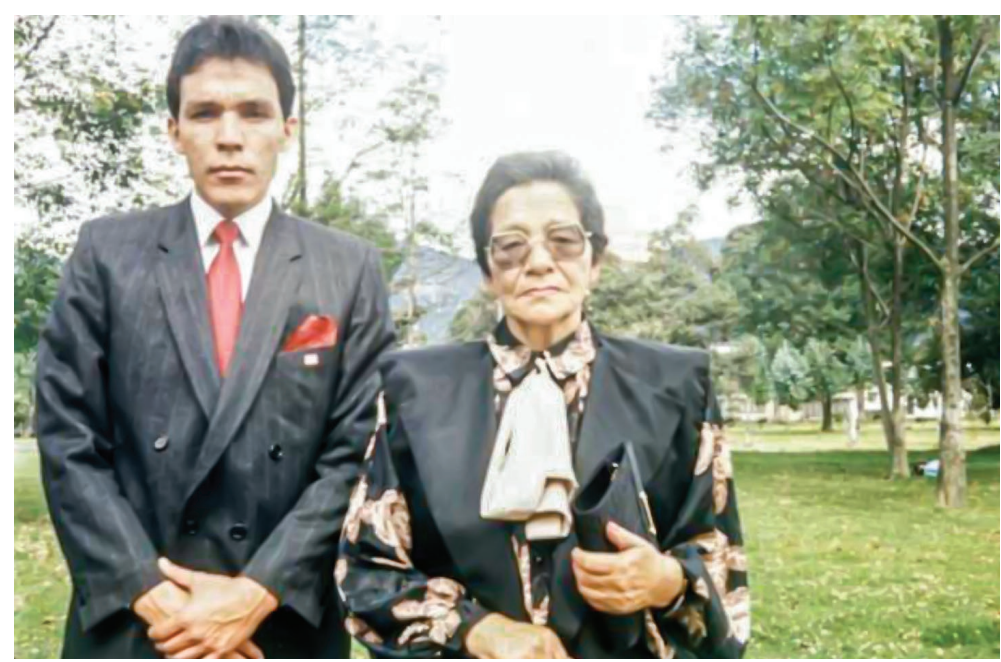

Foto 8. Mi abuela Ana con mi tío Carlos en su grado.

Universidad Nacional de Colombia. 1987.

A veces siento como si la genética hubiera dado un salto generacional y hubiera decidido poner en mí cosas de mi abuela Ana que mi mamá no le heredó. A veces parezco una abuela, parezco mi abuela. También soy ella, ella también escribe conmigo. Aunque hace más de 16 años su corazón haya tenido una falla y haya dejado de funcionar, el corazón de mi abuela sigue escribiendo conmigo. De mi abuela Ana, que no se llamaba Ana, pero estoy segura de que no le hubiera gustado que revelara su verdadero nombre, aunque sea nombre de princesa rusa. A ella también le hubiera gustado que yo me graduara de la universidad, y mejor, de la Universidad Nacional de Colombia. Eso también me tiene acá sentada, escribiendo con afán porque, aunque el tiempo no existe, sigue corriendo y yo tengo que entregar este trabajo terminado, aunque hace mucho rato lo terminé.

El evitar el egoísmo es imposible. ¿Sólo estoy escribiendo para mí?, ¿por mí? Pero si es que yo soy todos. Me siento ridícula; el ruido de las teclas en cierta forma me fastidia, porque escribo pensando que es para otros; tiene que ser para otros porque yo ya sé todas estas cosas que escribo. Pero simplemente me dejo llevar por la escritura porque es un requisito graduarme este año. Y tal parece que de lo que aquí escriba depende eso. Muchas cosas se me habrán olvidado, cosas que pensé y también que escribí, y también seguramente se me ocurrirán muchas cuando ya lo haya entregado. Eso no debería preocuparme, porque todo es lo mismo; el mismo todo. Pero estoy revisando todo lo que he escrito antes y tratando de darle un orden. 
La única pretensión de esto es la de ser lo más sincera posible. Y también sincera conmigo.

¿Qué pasará con todas estas hojas?, ¿con todas mis cosas cuando yo ya no esté? Las reciclarán. ¿Y yo dónde quedaré? Yo ya estoy en estas hojas. Acá existo. Y posiblemente en ningún otro lugar. Existo en este esfero que ahora es tinta. No quiero llegar al límite de la locura, pero sé que me arriesgo escribiendo esto que escribo y que ya escribí.

¿Estaré aumentando mi producción de dopamina?, la sustancia que producen en exceso los esquizofrénicos. Desde que retomé esto duermo menos. Me levanto a escribir. Me da menos hambre. Esto ya lo había vivido. ¿Merece un diploma de grado en antropología esto?, ¿volver a las cosas tan duras que ya experimenté? Todo pareciera indicar que sí.

Pero como el tema son los refugiados, un tema antropológicamente muy interesante, me tendré que saltar muchas hojas de mis diarios de campo que eran cualquier cosa menos eso. Me salto hasta la primavera del 2000, cuando llegué a ese centro, aunque, siguiendo mi coherencia incoherente, siempre he estado ahí, con ellos.

\section{La Reina de la Paz}

"Il mangiare è pronto, ¡tutti a tavola!". La comida está lista, ¡todos a la mesa! Luego de esas palabras comenzaba el desfile; todos ante mis ojos: chinos, afganos, hindúes, pakistaníes, somalíes, turcos, rusas, moldavas, rumanas, iraquíes, marroquíes, etíopes, colombianas, palestinos, kurdos, ecuatorianas, congoleños, búlgaras, armenios, bengalíes, kosovares, egipcios, ucranianos, albaneses, nigerianos, polacos, bosnios, argelinos, ghaneses, , serbios, tunecinos, croatas, bolivianas, sierraleoneses e italianos.

Todos pasaban delante de mí porque todos tenían hambre: a todos nos da hambre. Eso para mí en ese momento, que es el mismo en que ahora escribo, no era tan obvio. Además, tiempo después lo leí en un libro de un señor de esos que escriben; que lo único que tenemos en común es que a todos nos da hambre. Lo leí en Al calor del tropel, de Carlos Medina Gallego, que un día se graduó de la Universidad Nacional de Colombia. Lo leí hace poco, pero lo importante es que yo en ese momento lo sentía: la hora de la comida era el único momento en el que todos hacían lo mismo; en el que todos hacíamos lo mismo. Para cada uno de ellos, de los inmigrantes o prófugos de guerra, había un número que lo identificaba. Para mí no, pero en este momento me identifica uno en las listas de la carrera de antropología, de la Facultad de Ciencias Humanas de la Universidad Nacional de Colombia. 
Con ellos, con esos seres de múltiples colores, compartí mi vida durante tres meses y medio. Yo era solo una más en esta conjunción infinita de lenguas, de historias, de verdades, de costumbres, de vidas; sobre todo esto último. Pero como lo que quiero es graduarme de antropóloga, y el estar viva no es suficiente, intentaré teñir de colores antropológicos y etnográficos lo que ante todo fue y continúa siendo sólo una parte de la continuidad inevitable e infinitamente constante de mi vida.

Eso no quiere decir que no lo disfrute; me estoy disfrutando el escribir esto mucho más de lo que pensé. Por lo menos por eso ya valió la pena.

Estuve con ellos cuando la tierra había dado 2000 giros completos y un poco más alrededor del sol, desde el nacimiento de Jesucristo. Yo sentía que en ese momento ese dato no tenía la más mínima relevancia, y posiblemente ahora tampoco, aunque El Hombre del Milenio hubiera pretendido hacerme creer que sí. Ahora, cuando estoy sentada frente a esta pantalla escribiendo, ese tiempo es el único que existe. Ese, mi presente, se hace eterno en estas líneas teñidas de colores. Ahora estoy sólo yo, escribiendo y viviendo una vez más y como siempre con todos ellos: 林麟 (Lin Lin), Mohamed, Sinavera, Светлана (Svetlana), Hevindar, 慈恩曹化 (Cí̀ēn Cáo Huà), Ramzina, Катя(Katia), Ramona, Hikmete, Hussein, Женя (Zhenya), Bakarí, 辖小力(Xiá Xiăo Lì), y todos los demás. $\mathrm{Su}$ historia, mi historia ya no es la misma; solo por el hecho de estarla escribiendo la estoy viviendo. Es esa la eternidad de mi presente. Mi presente que no será el mismo cuando este escrito sea leído.

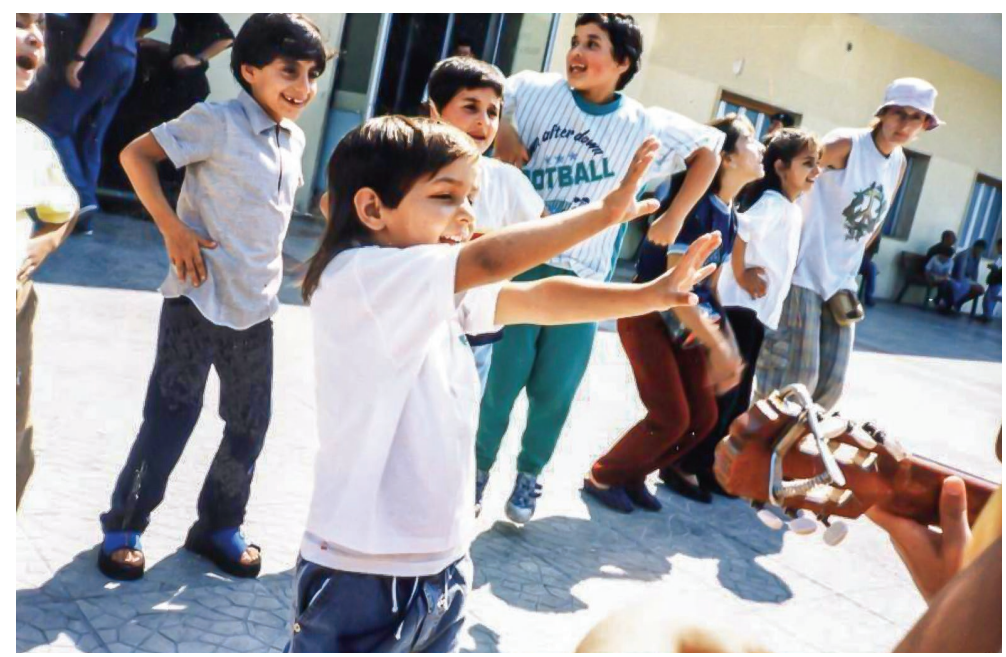

Foto 9. Sinavera, Mizcin, Hikmete, el hermano de Hevindar, Hevindar, Flonza, Idaeta, Cristina, Alicia y yo detrás y adelante otros más. 
Solo voy con mi pena, sola va mi condena, correr es mi destino para burlar la ley, perdido en el corazón de la grande Babilón, me dicen el clandestino por no llevar papel. Manu Chao es uno más de los que escribían conmigo, como Edgar Morin, Félix Guattari y Pier Paolo Montà, que para los que no se acuerdan, tiene síndrome de Down. Y le gustan los Beatles. Yo los escuchaba con él y también los escucho ahora que escribo en mi casa en Bogotá, lejos de Pier Paolo, y como siempre, con él. La música también ha escrito conmigo, pero la impresora no imprime música, aunque ella ya está acá. Los Beatles, Manu Chao, y también Silvio Rodríguez me acompañaban en ese viaje, en el que al final solo quedarán nuestros cuerpos tendidos al sol. Ellos también dicen cosas que escribía y que escribo. Si pudiera meterle música a esto le pondría la pizzica, una música del sureste de Italia que me gusta mucho y que me acompaña y me acompañaba en el mismo sureste de Italia en el que estaban los refugiados que seguramente nunca la conocieron, así como tampoco a ese mar Mediterráneo que tenían al frente, al que yo me metí una vez cuando estaba en Cartagena con Arnulfo.

"Nella casa Regina Pacis siamo tutti fratelli e siamo tutti uguali". En la casa Regina Pacis somos todos hermanos y somos todos iguales. En la casa de la Reina de la Paz todos somos iguales y todos somos hermanos. Eso estaba escrito en varios idiomas en el comedor, el único sitio que nos reunía a todos al mismo tiempo, en el que todos hacíamos lo mismo.

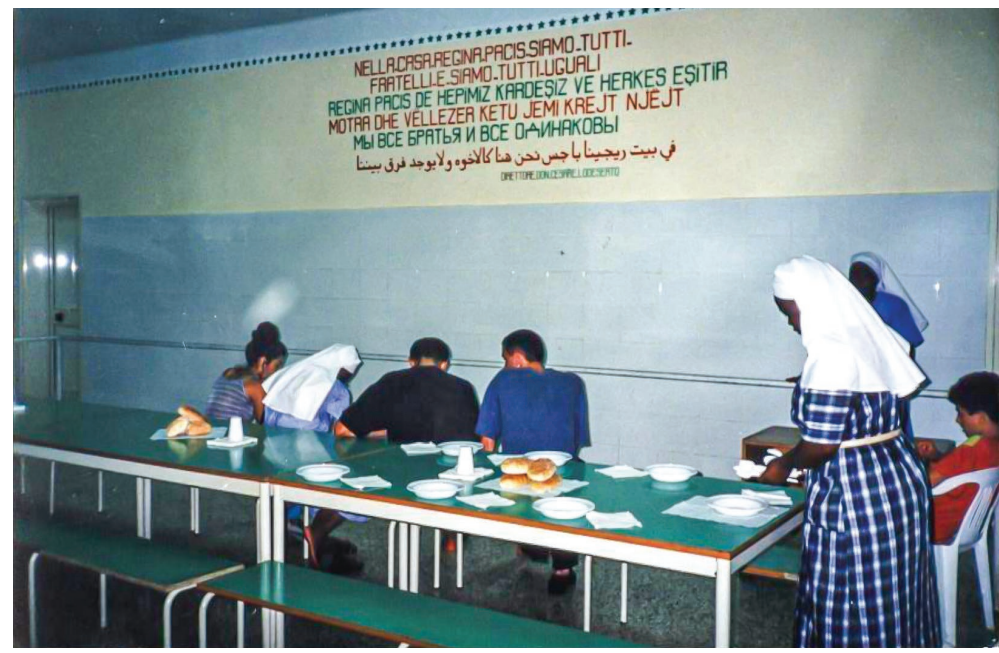

Foto 10. Donde todos éramos iguales y todos éramos hermanos. 
Todos éramos iguales. Y todos diferentes: Mihaela, la gitana rumana de 19 años había sido robada por su marido, él se la robó; ahora ella pedía limosna en las calles con sus dos hijas. Коста (Kosta), el muchacho serbio de 15 años, estaba detenido por no tener documentos; él hablaba muchas lenguas eslavas que había aprendido en el colegio y además hablaba casi perfecto italiano. Катя (Katia) era rusa, era prostituta y se maquillaba con colores muy fuertes, igual que la otra Катя, también rusa y también prostituta; ellas eran todas iguales: también eran políglotas y hablaban muy bien el italiano, pero eran prostitutas. Las madres musulmanas con su cabeza cubierta pasaban al comedor con sus hijos; ellos no comen cerdo, son musulmanes. 陈琴侵 (Chén Qín Qīn), más conocida como Chin Chin, la chinita tierna de 20 años no quería aprender italiano, ella solo trabajaba en la cocina. Ramona, la prostituta, la misma que ha publicado libros de poesía en Rumania, se adelgazó 22 kilos porque no le daban de comer cuando estaba secuestrada en Yugoslavia, ella entiende español porque veía telenovelas mexicanas en Rumania. Paolin Dogay es albanés, trabaja en la oficina y no sabía quién soy yo ni qué hacía ahí, no conocía ni siquiera la asociación de voluntariado que me había mandado a trabajar allí, nadie le dijo nunca que era mi tutor, la persona a la que yo podía recurrir si tenía problemas durante mi intercambio. ¿Problemas? Problemas los de esa gente que estaba ahí recluida; "¿usted qué quiere de mí?” me preguntaba con rabia. Mirella, la albanesa de 17 años, fue víctima de una violación múltiple; ella decía que yo era su hermana. Jhony el iraquí trabajaba en la oficina y le daban carro; trataba mal a todos, pero es muy atractivo. Mizcin es linda, tenía 6 años y es kurda; hablaba casi perfecto italiano y francés. Tiene ojos de hambre. Su papá, que trabajaba en la cocina, cogía la comida para ella y sus cuatro hermanos cuando creía que nadie lo estaba viendo. Luca, el italiano hijo de uno de los jefes del Centro quería ir a Colombia; varios de sus amigos lo han hecho. Yo ingenuamente creía que, como es moda en estos tiempos en Europa, tenía ganas de conocer la cultura latinoamericana. Pero él quiere ir a comprar cocaína, "es lo único que atrae a los lecceses (de Lecce, capital de la región de la Puglia) de Colombia". Un marroquí me pregunta interesado cómo hacer para ir a Colombia, él quiere volverse mafioso. 慈恩曹化 (Cí>ēn cCáo Huà) me miraba y nos reíamos; no sonreíamos, nos reíamos; él nunca aprendió a decir "yo me llamo..." en italiano, a pesar de todos mis intentos por enseñarle. Los policías en la carretera me detenían: - "Sus documentos, por favor" - "Soy voluntaria." "Mmm... voluntaria... ¿así las llaman ahora...?" Y los otros policías, los de adentro del Centro no me dejaban salir: - "Acá no se puede salir" - "Yo sí, soy voluntaria". Mohamed, "Mishko", es el coordinador de la cocina, tenía 20 años y lo único que quería era irse 
a América, a los Estados Unidos. Las dos colombianas, de Buenaventura, querían que yo les sacara la comida a escondidas. "Mirá, vé, yo soy de Cartagena" y yo le creí a una de ellas, a pesar de haber vivido siete años en Cali. Yousef, el palestino, estudió ingeniería becado en la Universidad de París; él también tenía hambre y tenía que hacer la fila para que yo le diera su plato de lentejas. En esta casa somos todos iguales. Carla, la voluntaria romana de sesenta años se ponía brava porque yo no le entendía cuando me decía que le pasara "i fazzolettini"; es que a mí me enseñaron que servilleta en italiano se dice "tovagliolo". Pat, la nigeriana que no se llamaba Pat, acababa de salir de la cárcel por tráfico de drogas; ella era muy tierna con los niños. Mustafá, el del almacén de ropa decía que no había zapatos para los niños de Kosovo, pero Milena besaba rico y todos los días salía del almacén con ropa nueva. Dilan, el iraquí que se suponía que estaba loco, besaba la cabeza calva del cura, el director del centro, y gritaba "BBasta fanculo, dammi il soggiorno!"; "Basta, vete a la mierda, dame el permiso de residencia". Él hacía dibujos hermosos sobre un papel y decía tiernamente: "Dilan no scemo", Dilan no es bobo. Uno de los directores del centro estuvo en la cárcel; salió en los periódicos por estafador. La familia Beraj es de Kosovo; habían llegado en barco con sus diez hijos preciosos de entre tres meses y quince años; la mamá de ellos quería que yo le depilara las cejas porque está de moda. Hevindar, la niña kurda de ocho años también había llegado con toda su familia; sus papás le pegaban a ella y a sus cuatro hermanos porque estaban bailando en el patio. Giorgio, el romano rabioso nos regañaba a todos todo el tiempo; cuando me iba de viaje me regaló dulces para el camino. Женя (Zhenya), la ucraniana, era muy bonita, era novia de uno de los policías de la casa Regina Pacis, muy maquillada y vestida con ropa costosa iba a pedirle permiso al cura para salir con su novio. Ramzina la iraquí decía que era imposible que yo aprendiera árabe. Es simplemente imposible. Solo me enseñaba los números como si estuviera aprendiendo a contar con los dedos; ella no podía concebir que existiera alguien que no tuviera religión. "¿Cómo es posible?, ¿pero no eres católica ni musulmana ni nada?" "No lo puedo creer!". Mizcin, la niña kurda me decía: "Si comes cerdo, eres cristiana". María, la albanesa, estaba desesperada porque no podía fumar; le vendió su cuerpo a un turco por dos cigarrillos. Las voluntarias italianas, de Mantova, que tenían 20 años -igual que Mishko-, hijas de la amiga del cura, iban como voluntarias por unos días; trabajaban una hora al día y el resto del tiempo se iban a la playa; es verano, hay que divertirse. Uno de los policías de alto mando del Centro era cliente de Milena, una de las de Buenaventura, antes de que la llevaran presa; a mí me llamaron de la oficina de la policía a regañarme por ser amiga de ella y favorecer la inmigración clandestina en Italia. "Eso no es correcto, Lucía". 


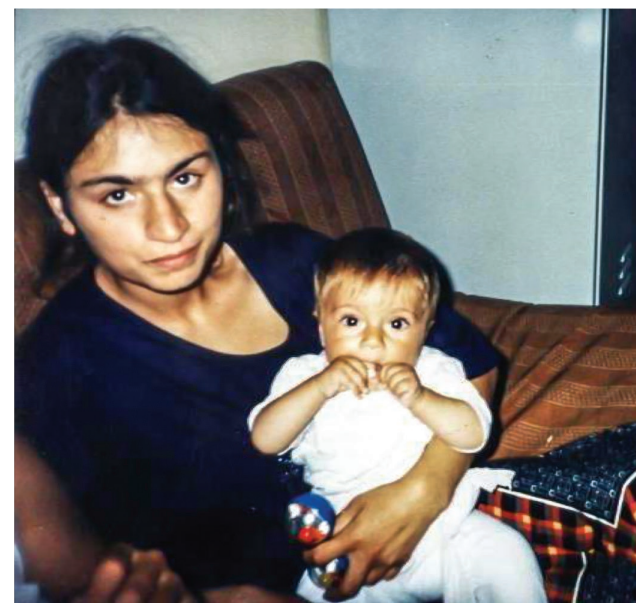

Foto 11. Mihaela, la gitana que había sido robada por su marido, con Esmeralda y yo detrás.

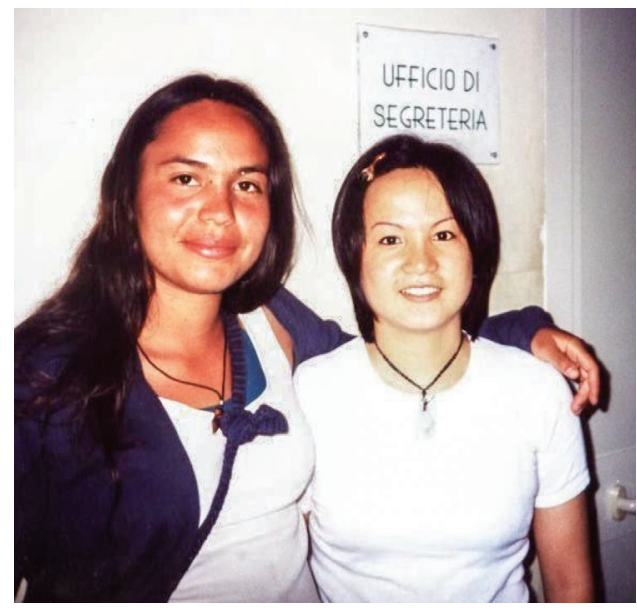

Foto 12. 陈琴侵(Chin Chin) y yo.

En esta casa somos todos iguales; lo decía en muchos idiomas en el comedor. Pero el cura, el director del centro, comía pastas finas con frutos del mar en bandejas de plata, excepto cuando los de la televisión iban a hacer reportajes. Yo lo veía esconder el postre y el cojín de su asiento. Acá en Regina Pacis todos somos iguales. Pero él tenía un carro que valía 100'000.000 de liras, que eran más o menos cien millones de pesos. Renata, la asistente del director es ucraniana; ella y el cura comían hasta reventar, hasta que tenían que botar la comida porque no les cabía más. El hijo de Renata era el único niño del Centro que iba al jardín infantil, era gordito y cachetón; estaba muy bien alimentado. Pero Renata también había sido prostituta, como Ира (Ira), Наташа (Natasha), Nelly у Петрова (Petrova), la rusa que se ponía brava conmigo 
porque no le daba más comida. Me insultaba en su idioma, que en ese momento me hubiera gustado saber para decirle que no me gritara y que no le iba a dar más pan, pero ella iba a seguir gritando igual.

Ramzina se compró un reloj de 260.000 liras, pero ella y su hermana Maria son pobres; ellas pedían asilo político porque en Irak no tenían posibilidades de salir adelante. Ellas querían tener celular y ropa cara, igual que las rusas, moldavas y ucranianas; todas eran iguales. No hacían fila para comprar en la tienda del centro porque ellas son mujeres; todos somos iguales en esta casa.

Los policías les pegaban a los detenidos. Pero para mi sorpresa llegaba el cura y les decía a los policías que los dejaran en paz. Y después me daba cuenta de que había visita; visita de las damas de la Sociedad que daban donaciones a la casa Regina Pacis, donde todos éramos iguales. Cuando iban los inspectores había que ponerse guantes para servir la comida, pero cuando un día común y corriente yo los pedía me decían que había que economizar. "Es un zulú, un deficiente este Domenico", decía Carla la romana, acerca de otro voluntario italiano, "al menos se civilizó, compró celular".

En la casa Regina Pacis todos somos hermanos. A todos nos daba hambre. Todos estábamos tristes, todos locos, todos capos, todos bravos, todos peleaban, todos nos enamorábamos. Катя (Katia) era novia de un árabe que le ordenaba que le sirviera la comida y la regañaba porque le había llevado galletas y él no quería, ella estaba enamorada. Angela es moldava y estaba enamorada de un palestino, pero no se podían comunicar, entonces me pedían que les tradujera: "Él dice que si te quieres casar con él". Una de las mujeres de Buenaventura y uno de los hombres de Turquía tenían que pasar por dos traductores para poder decirse que se gustaban. Los árabes casi siempre con las rusas; una de ellas, Катя, se casó con un italiano. Maria, la iraquí hermana de Ramzina, estaba enamorada de un italiano.

Mientras Bakarí me decía que se quería casar conmigo, yo esperaba todos los días a que apareciera a comer el 10121 para ver sus ojos rasgados y decirle "Ni hao". Si en ese momento hubiera sabido hablar chino le habría dicho: 你好林麟, 之你好吗? 我很好, 谢谢。

¿我去游泳, 好吗? 认识你, 我很高新。Hola Lin Lin, ¿cómo estás? Yo muy bien, gracias.

¿Quieres ir a nadar conmigo? Estoy muy feliz de conocerte. 
Si en ese momento hubiera sabido hablar chino tampoco le hubiera dicho nada porque de solo verlo me temblaba la voz, se me aceleraba el corazón y me sudaban las manos. Tampoco le hubiera dicho nada.

Todos necesitan compañía, todos se enamoran en esta casa donde todos somos iguales. A veces las prostitutas también se enamoraban de sus clientes.

Un chino cantaba con pasión y sentimiento las canciones árabes que le enseñaba Yousef, el palestino. Es inevitable sonreír cada vez que lo recuerdo. Él me entendía cuando le preguntaba en chino su nombre, y me respondía “我是林银幕”. "Yo soy Lin Yin Mu". Las negras de Buenaventura se quejaban porque "todas estas putas tienen sobaquiña". En África se escucha salsa, dicen los africanos cuando los pongo a escuchar en mi walkman. "Esta música me es muy familiar", me decía Bakarí. Es que éramos lo mismo.

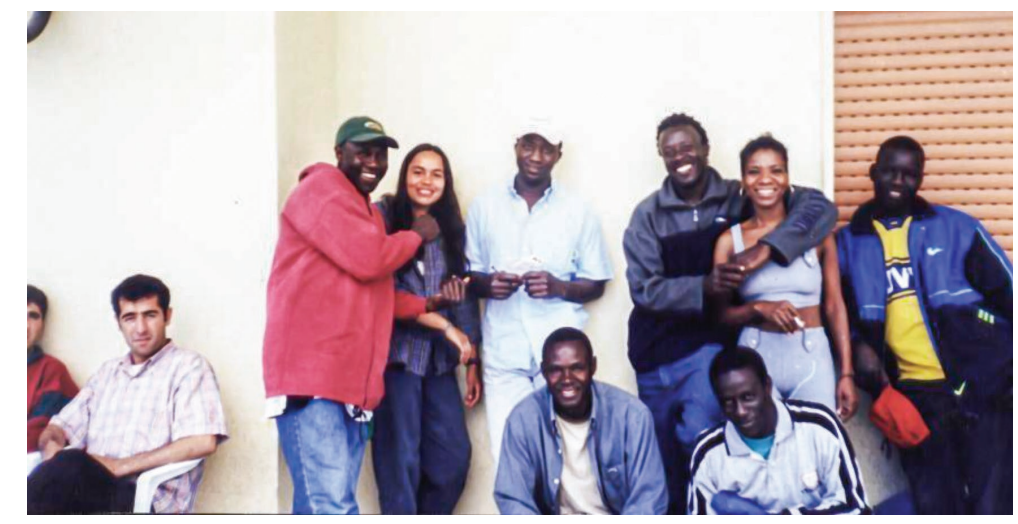

Foto 13. Bakarí conmigo y con turcos y Milena y más africanos. Todos lo mismo.

El juego de cartas entre chinos, palestinos y africanos de varios países solo constaba en tirarlas a la mesa; me pasaron algunas cartas y me dijeron que jugara. - "Pero ¿a qué están jugando?", "eso no importa, juega con nosotros". Y todos tirábamos cartas a la mesa y nos reíamos. Estábamos hablando el mismo idioma.

Las mujeres de Europa Oriental eran supersticiosas; me leyeron las cartas en ruso con traductora moldava. Eran iguales a Milena, que cree ciegamente en lo que le dice el tabaco.

Una taiwanesa que también estaba de intercambio en Italia y me enseñaba algo de chino para poder hablar con 林麟 (Lin Lin) me regaló un amuleto chino para la buena suerte y me lo robaron en un semáforo en la carrera 30, en el sur de Bogotá. Eran dos las taiwanesas que estaban de 
intercambio; eran vecinas de los chinos y hablaban su mismo idioma, pero ellas sí estaban de paseo.

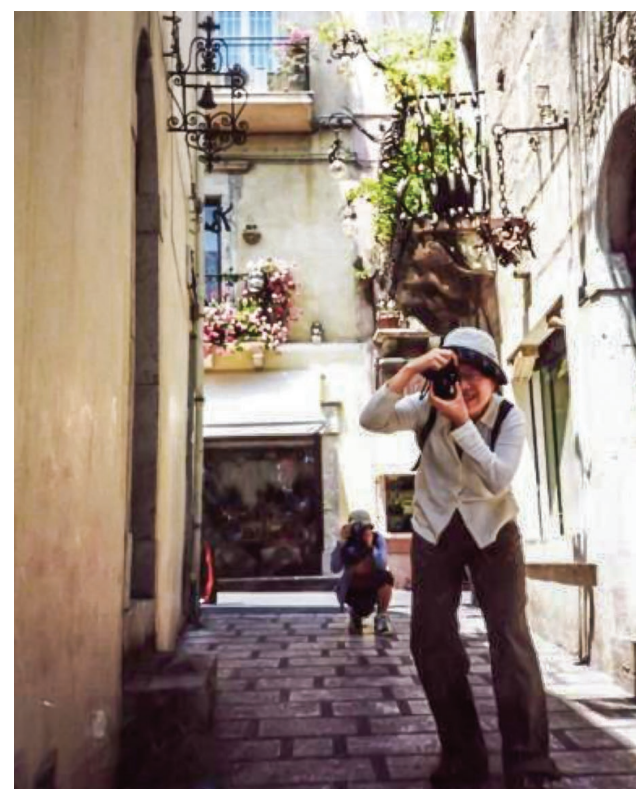

Foto 14. 林荫纯 (Lín Yinn Chún), 陈车瘾(Chén Chē Yǐn) y yo en Sicilia.

Todos tienen hambre; - "¿Quieres cerdo? ¿Pero acaso no eres musulmán?" - "No importa, tengo hambre". Una de las moldavas, esas que tan mal me trataban, lloraba desconsoladamente porque se le iba su amiga rumana; ella y sus amigas se enternecían con una muñeca, querían jugar con ella. Ellas tenían 20 años y eran prostitutas. 林麟 (Lin Lin) bailaba danzas de Afganistán con 魭鸣 (Cháng Míng). Era muy bonito, todos bailaban y se abrazaban, también los turcos y las rumanas.

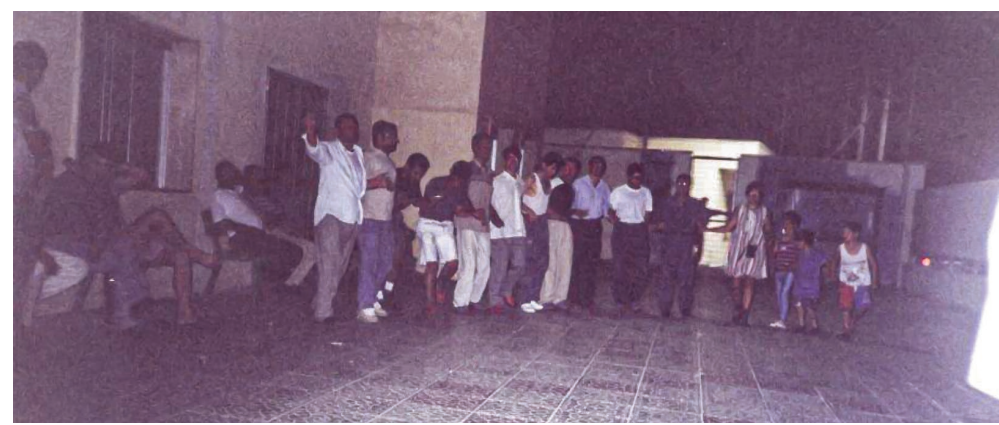

Foto 15. Bailando en el patio de Regina Pacis.

En el comedor todos tienen hambre; las rusas me hablaban en ruso, los chinos en chino, los turcos en turco, el palestino en francés; 
todos ellos me estaban pidiendo comida. Todos también nos reíamos de lo mismo: la nigeriana, la china, el iraquí, la moldava, el italiano, la colombiana; todos riéndonos de lo mismo sin hablar. En el comedor un chino - que es de los que no peleaban con nadie- se agarraba a golpes con un yugoslavo. ¿En qué idioma estarán peleando? En el mismo de todos. Allá todos peleaban, hasta los que no peleaban. Uno de los palestinos, que era novio de una de las moldavas, siempre me agredía porque no le daba más comida, pero un día no me regañó; estaba triste porque quería ser libre y estaba preso.

Acá todos somos iguales: todos quieren mandar, todos tenemos la respuesta, todos capos, todos jeques, todos caciques, todos emperadores. Silvia es moldava; tenía 20 años y un hijo de dos; era divorciada. Me contaban que había ido por gusto. "¿A qué tenía que venir a Italia a prostituirse teniendo todo allá? Le gusta mucho mandar y tener plata". También a mí me regañaba, y eso que yo no estaba detenida. Pero es que acá somos todos iguales. Silvia salía en televisión y contaba la historia de cómo la engañaron en Moldavia para llevársela a trabajar a Italia. Nelly, una de las prostitutas rumanas me decía: "La que diga que no sabía a lo que venía está mintiendo; todas lo sabemos, todas somos putas".

Una noche tuve que ofrecerle -en inglés que yo no sé hablara una nigeriana que decía ser jamaiquina, un futuro mejor; ella podría venir al centro y conseguir un trabajo honrado. Pero es que ella quería ser prostituta. Raquel también estaba en Regina Pacis, era del Eje Cafetero. Ella no quería dejar la prostitución porque gracias a ella había comprado casa y carro en Armenia. Si trabajara como empleada en una casa no se podría dar esos lujos. Los chinos repetían: "dollars, I want dollars". Las rumanas y rusas eran solo unas niñas cuando las trajeron a Italia a prostituirse; muchas de ellas intentaban suicidarse. ¿cuántas lo habrán logrado? Sigurður, un amigo islandés que también estaba en Italia de intercambio y trabajaba en un centro para inmigrantes en Bolzano, en los límites con Austria, me escribía cartas y en una me decía: "Solo quieren hacer disturbios, se enojan porque no se les da la comida que quieren, no quieren obedecerme, malditos kurdos".

Para las rusas, los chinos y afganos eran la misma cosa; a todos les decían: “China!”. Un día sirviendo la comida, en el comedor había un muro que me impedía verles las caras; solo se veían las manos, las manos de todos que eran iguales.

Todos éramos iguales allá, pero yo era voluntaria; yo podía salir cuando quisiera. 
Llegaban y llegaban turcos de Turquía y de otros lados mientras el mar se ponía cada vez más azul; cada vez tenía más color de verano, del verano mediterráneo. Yo salía y me comía un helado de muchos sabores mirando el bellísimo mar azul mientras ellos no podían salir.

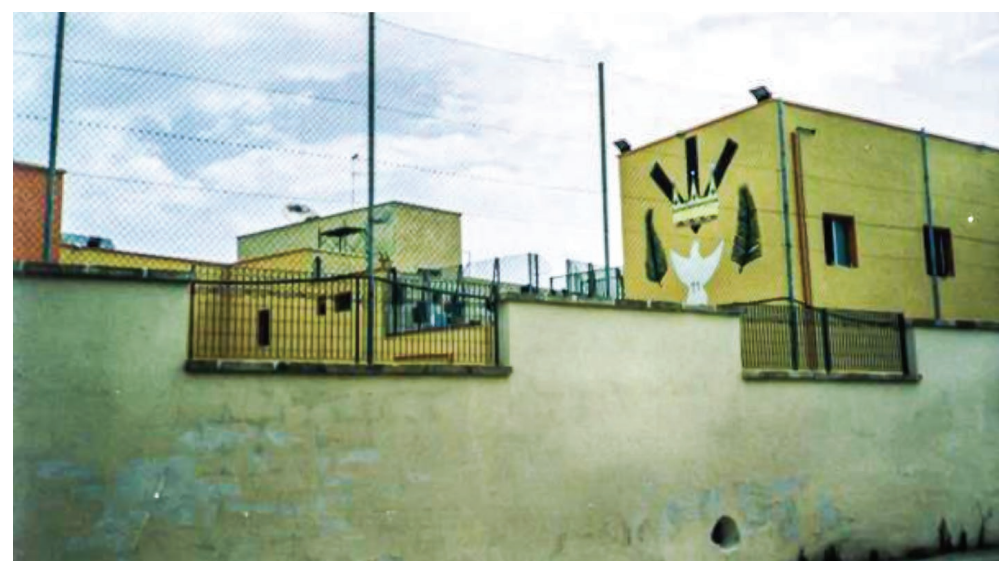

Foto 16. Desde afuera.

¿Somos todos iguales? Sí, pero unos son más iguales que otros; a algunos les daban permiso para ir al mar.

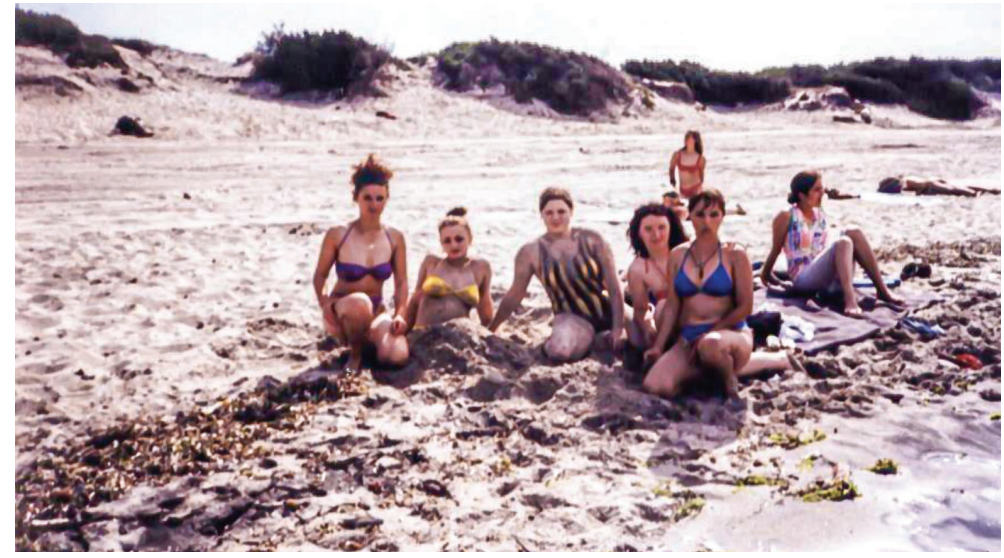

Foto 17. Rusas, moldavas, rumanas en la playa del frente.

Mientras escribía en papel todo esto, mi escritura adquiría características chinas; yo escribía al revés sin darme cuenta. Todo el tiempo escribía y leía, sobre todo a ellos.

Un día estaba leyendo La vida es sueño, de Calderón de la Barca, y una de ellas, Катя (Каtia), о Наташа (Natasha), no me acuerdo cómo se llamaba, me preguntó si estaba leyendo en español. Ella no sabía que 
estaba siendo soñada por mí y que yo era su sueño en ese momento eterno. Un sueño compartido por todos e infinitamente solitario.

\section{Escribiendo y mirando por otra ventana}

Mientras tanto, mientras estaba allá siendo parte de ellos y ellos de mí, soñaba con mi cotidianidad en Colombia, con mi familia; los personajes se entremezclaban unos con otros.

\section{¿No somos acaso lo mismo?}

Yo sentía, vivía, sufría, llamaba a mi mamá llorando porque se llevaron del centro a la familia Beraj, la de los diez hijos kosovares. Todavía en Colombia, mucho tiempo después, los recordaba y lloraba.

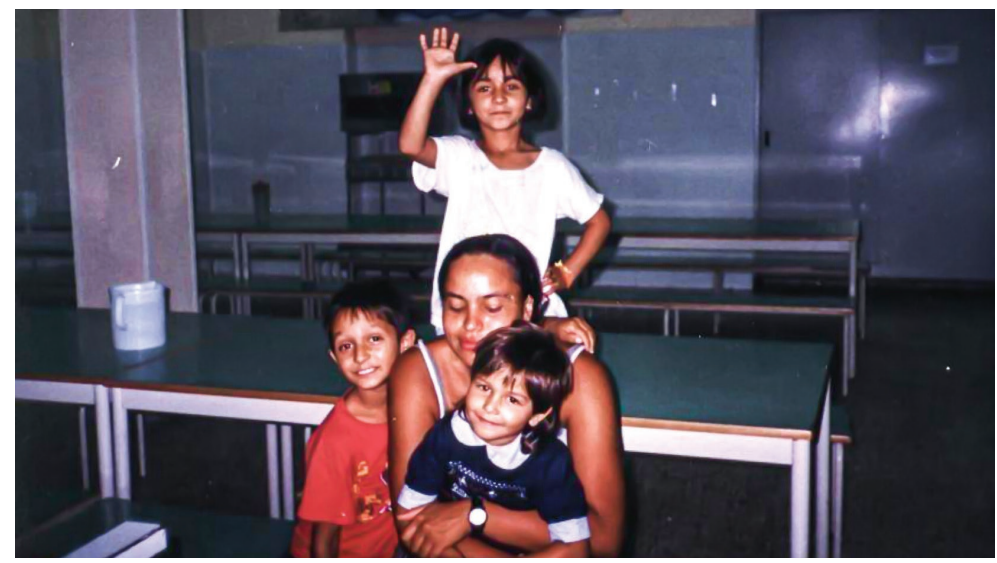

Foto 18. Sinavera, Ferdi e Hikmete, tres de los niños de la familia Beraj.

Me daba rabia cuando el cura, arzobispo o lo que sea me empujaba la cara con los dedos. “¿Cómo va el trabajo?”. Yo no comprendía sus gestos y me daba mucha rabia; ¿debo aceptarlo también como una simple manifestación de una cultura diversa? Yo no soy católica, aunque Mizcin creyera que sí porque comía cerdo. Un iraquí me dijo: "Ese es uno de los grandes", ¿y a mí qué me importa? En la casa Regina Pacis somos todos iguales.

Yo me sentía mal cuando Mirella me servía la comida; le dolía la cabeza. No me sentía bien exigiendo mis derechos como voluntaria viendo a los refugiados, pero ¿qué podía hacer? ¿aguantar hambre con ellos? Sí, algunas veces lo hice. Yo salía de allá y veía los niños que se quedaban con cara de que querían que me los llevara con ellos; todos querían salir, querían trabajar y tener plata. 
Me daba rabia con el cura, con el director del centro, que maltrataba a los refugiados y se enriquecía con las donaciones. A veces me daba rabia también con ellos, porque siempre querían más. A mí no me parecía mala la comida, todos los días comían fruta.

Me enternecían los chinos, me caían mal las rusas que me gritaban todo el tiempo, me daba rabia con las visitantes del centro que iban y los miraban como en un zoológico. Todos estamos en un zoológico; unos se disfrazan de una cosa, otros de otras. Unos de antiguos romanos para tomarse fotos con la gente y cobrarles, o de elegantes botones de hotel.

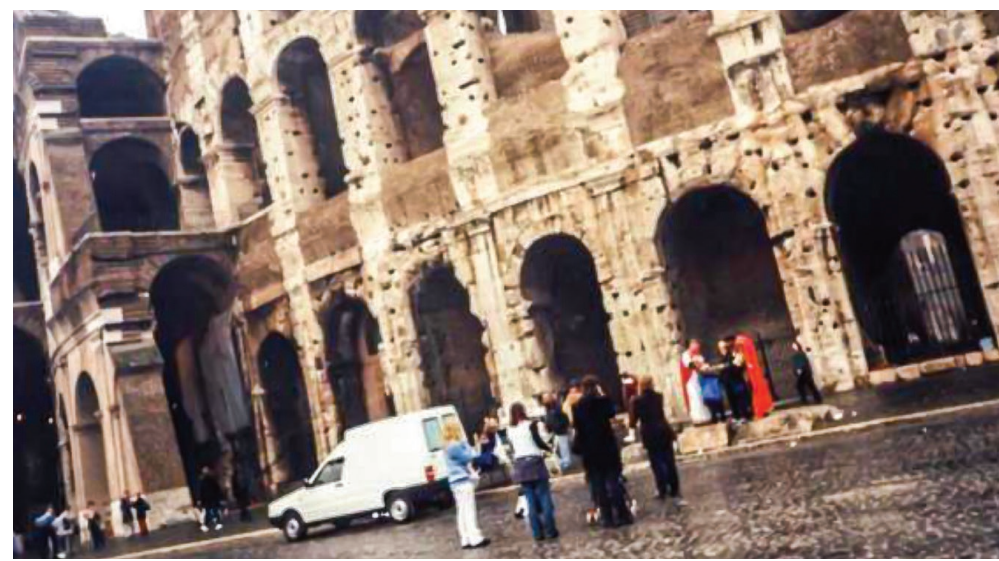

Foto 19. Los antiguos romanos y los de ahora, que son los mismos.

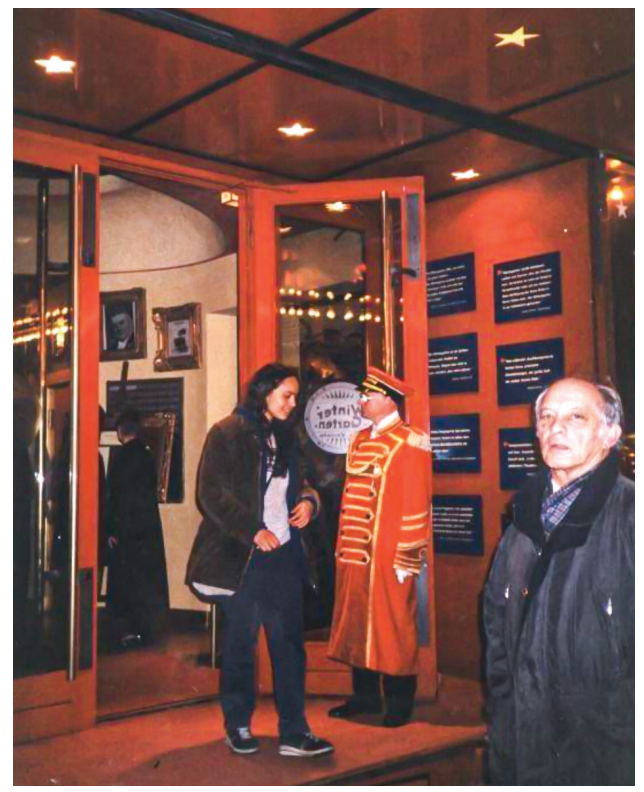

Foto 20. Botones de hotel en Berlín. 
Mientras ellos estaban allá encerrados yo salía de paseo; iba a Roma, a Berlín y a muchas partes, me iba de turista, pero me los llevaba a todos. A todos ya me los traje y aquí están, escribiendo conmigo. Escribiendo para mí.

Yo me iba de paseo y tomaba fotos. Les tomaba fotos a las personas y también al cielo; a las nubes mientras cambiaban de forma y nada cambiaba. Y hacía dibujos sin saber dibujar. Dibujaba en una misma hoja por lados opuestos el mismo sitio a la misma hora desde lados opuestos. Dibujaba en un lado a la luna y al otro al sol, y eran lo mismo. Y dibujaba al gato que me seguía y mis piernas que también eran parte del dibujo y la mochila que me hizo mi prima Ana María, sin imaginarme que ese dibujo iba a ser puesto como portada en mi trabajo de grado para optar por el título de antropóloga.

Pensaba en dejar la antropología y quedarme en Italia estudiando astronomía. Esas ideas pasaban por mi cabeza mientras les daba de comer a todos. Me arriesgaba rompiendo las normas para llevarles comida a los chinos; no quería que se fueran. Les cogí cariño, pero algunos se aprovechaban de eso; querían comer dos veces. Una de esas chinas se parece a mi tía Ubaldina, la hermana de mi abuela Ana, que era descendiente de Coper, una vereda de Moniquirá, en Boyacá.

Y también me enfermaba y quería a mi mamá. Allá todos me gritaban: la rusa, el kosovar, la ucraniana, la moldava, el albanés me decía "puta" porque no le daba dos pedazos de sandía. Yo no les decía nada porque es que yo soy antropóloga.

Y me hice amiga de Milena, la de Buenaventura; la esperaba en el hotel mientras ella trabajaba y después me llevaba flores y me decía que yo era su negrita hermosa. Nos hicimos amigas y nos enseñamos cosas; ella ha escrito mucho conmigo y yo con ella. Y fui a su casa en Buenaventura y conocí a sus hijos y a su mundo tan extraño; un mundo en el que hablaban otro idioma, en el que leían el tabaco, hacían brujería y en el que todos salían a la calle a rebuscarse lo del almuerzo. Un mundo como todos los demás. Era un planeta extraño en el que cuando me miraba al espejo me sentía rara por no tener la piel negra. 


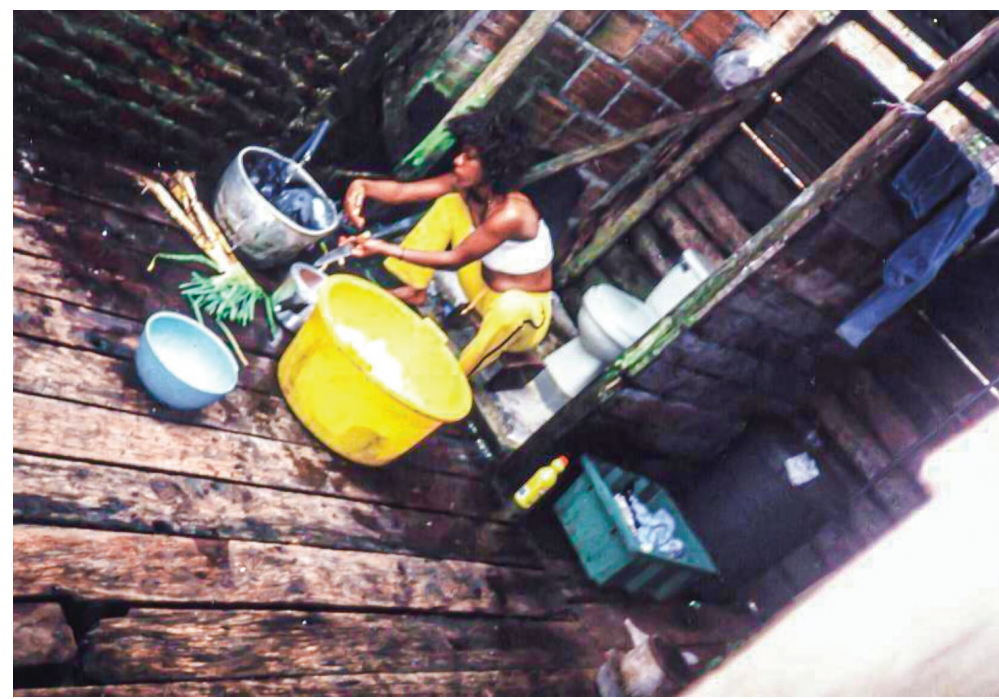

Foto 21. Milena en su casa en Buenaventura.

Buscando cosas acerca de Regina Pacis en Internet, me encontré con que el cura director del centro está en un proceso penal por violar los derechos humanos y por enriquecerse con los fondos de Regina Pacis. De eso se han hecho hasta películas; unas que lo acusan, otras que lo defienden. Cada uno con su versión, cada uno con su mundo, cada uno con su visión. Esta es solo la mía. ¿La de quién más podría ser?

Me pregunto quién estará ahora allá. No sé, pero son las 10 a.m. En Regina Pacis son las 5 p.m., "Il mangiare è pronto, per favore tutti a tavola".

Ellos están allá y yo acá. En Colombia, en este espacio que ahora se llama así, porque antes era la Nueva Granada. Las fronteras están en constante transformación. Ya no existe la CCCP, la Unión de Repúblicas Socialistas Soviéticas, sino Rusia, Moldavia, Ucrania, Estonia, etc. Ya no existe el Imperio austrohúngaro sino Austria y Hungría. Ya no existe Checoslovaquia, sino la República Checa y Eslovaquia. Los de acá tenemos nombres y apellidos de otro continente, de otra región que también sufrió invasiones territoriales. Mi primer nombre se lo debo a una ópera de Giuseppe Verdi; el segundo viene de la luz, mi apellido es el de los hijos de Sancho. Soy una amalgama incomprensible; somos una amalgama incomprensible. Todos estamos revueltos. Juntos y revueltos y tan solos como mi soledad que escribe sola en este computador. De esto se trata esta vida que compartimos no sincronizadamente; cuando unos se van otros llegan y nunca hemos estado todos al mismo tiempo en ella. Pero ahora yo también estoy con mi prima María Claudia, a la que el cáncer decidió llevarse cuando tenía 20 años y estaba empezando a vivir. Ella empezó 
a vivir y acá se quedó, también conmigo. Ella y su hermana Ana María escriben también conmigo. Ana María siempre ha sido mi prima mayor; me enseñó a bailar y muchas otras cosas de la vida. Ella siempre me ha aconsejado y me ha ayudado a escribir. También me tomó la foto en la que estoy sentada escribiendo esto.

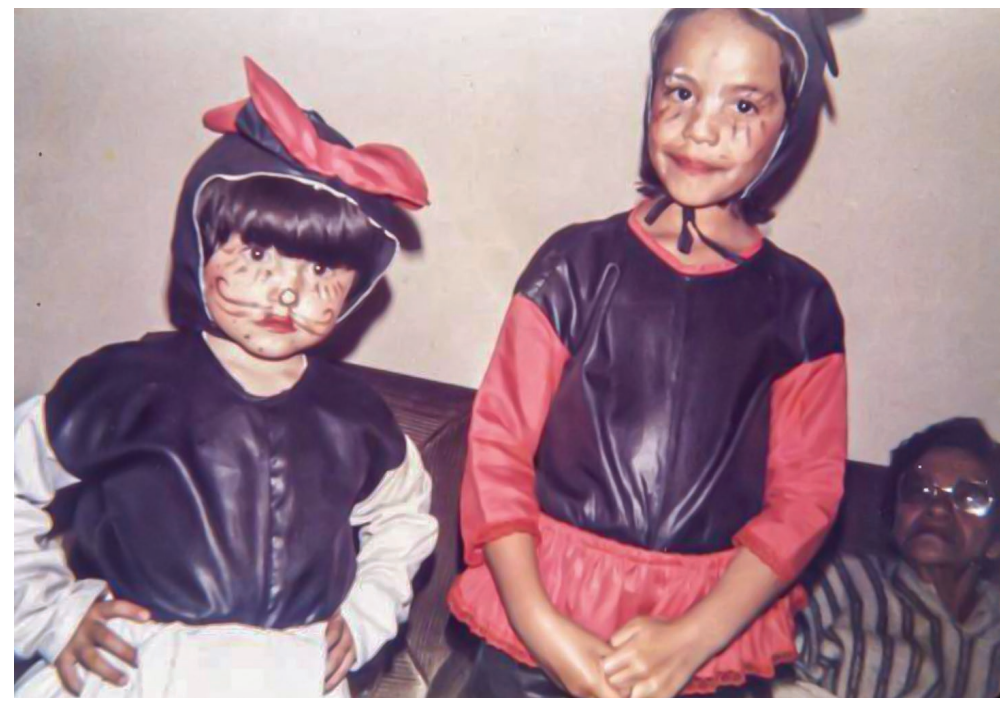

Foto 22. Octubre 31 de 1986. María Claudia, detrás mi abuela Ana y yo.

Mientras más me quise alejar de la antropología más me acercaba a ella. Era inevitable acercarme a las construcciones culturales del tiempo, el espacio y de todo lo demás. Yo estaba siendo una construcción cultural; mi nombre, el país del que era, el país en el que estaba. No estoy exagerando al decir que yo tenía que hacer planas con mi nombre porque a veces se me olvidaba. Yo solo era una parte de ese todo. Yo era ese todo. Si yo me moría todo se iba a acabar. Eso es lo que siento en este momento, en el que escribo con afán, pero con la tranquilidad de saber que finalmente nada va a importar.

En este momento pienso en la cantidad de páginas que tengo que entregar, ¿60?, ¿30? ¿Una tesis recortada? ¿Un ensayo agrandado? Muchos estudiantes de antropología se desilusionaron por la imposibilidad de un reconocimiento a un trabajo meritorio con las nuevas reformas al trabajo de grado. ¿El reconocimiento de qué?, ¿de quién? Si somos todos los que escribimos. También todos necesitamos una religión. Para muchos esa religión es el conocimiento. Tenemos necesidad de conocimiento, y de reconocimiento por ese conocimiento. Inter aulas academiæ quære verum. Todavía se pretende encontrar a la verdad entre las aulas de la academia. 
He dicho muchas veces que todos somos lo mismo. También la antropología. Y la historia, la economía, el arte, la lingüística, la matemática, la filosofía, la química, la física; todas son también parte de una constante transformación. ¿O energía? Algunos llaman a eso Dios. Yo no porque no soy católica, aunque coma carne de cerdo. Pero de ninguna de esas disciplinas puedo hablar, porque soy ignorante. Soy ignorante hasta en la carrera que estudié.

En este eterno fluir, energía, o como se pueda llamar, ¿qué puedo decir que sea mío?, ¿algo como para que pueda cumplir con los requisitos de una tesis de grado? Sinceramente no sé. He intentado usar la antropología, así como ella me usa. Somos lo mismo; soy todas las cosas mientras viva. No sé si la tierra gira o yo soy el centro del universo mientras escribo.

Lo cierto es que cuando entré a antropología no tenía idea de qué era que se trataba esto, ni siquiera lo sospechaba. Yo me la pasaba jugando con Gilberto y Alberto. Nos subíamos al monumento del parque Freud y le decíamos cosas a la gente que pasaba; jugábamos a la lleva, le poníamos apodos a nuestros compañeros y profesores y los dibujábamos. Eso era para mí en ese momento lo que significaba ir a la universidad a estudiar antropología.

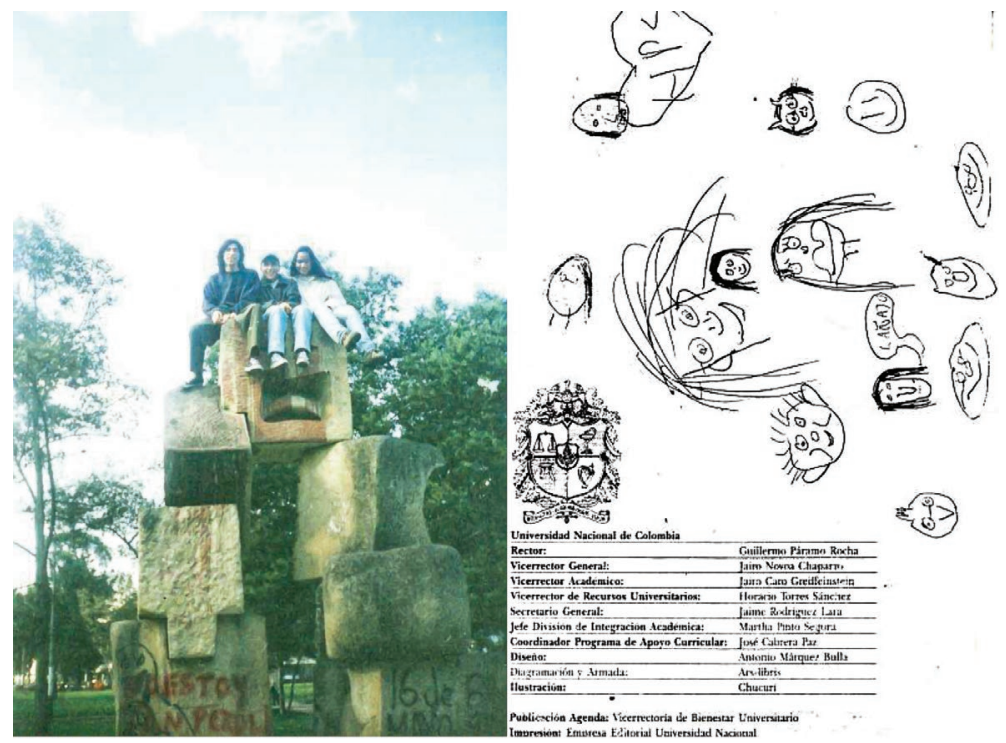

Fotos 23 y 24. 1998. Con Alberto y Gilberto. Nosotros y nuestros compañeros de semestre. Dibujos de Gilberto Roncancio. 
¿Necesito desarrollar más una idea? En realidad, esta forma de ver las cosas surgió de la experiencia de vivir con discapacitados mentales durante siete meses en Italia, pero solo necesité unas pocas semanas. A las tres semanas de estar trabajando con ellos ya estaba en una consulta psiquiátrica en Bogotá.

Pocas semanas también son el tiempo que me queda para que este trabajo alcance a ser evaluado por el comité y no perder la calidad de estudiante.

El tiempo no existe, pero está corriendo y yo tengo que entregar este escrito y me afano porque se va a acabar el plazo, aunque esto ya fue escrito hace mucho rato. Lo escribí un día que es el mismo que hoy porque todos los días son el mismo.

Yo escribía y la locura seguía ahí. ¿La esquizofrenia? Todos nos persiguen, todos están acá conmigo. Yo somos todos.

Escribiendo esto he tenido miedo de volver a tener esas sensaciones. Pero a esta hora de la madrugada en que escribo hay fiesta en el salón comunal del conjunto residencial en el que vivo y suena música que me hace acordar de cuando yo vivía en Cali y no me preocupaba la locura porque todavía no la conocía, no me la habían presentado. Esa música me tranquiliza. Cali pachanguero, Cali, luz de un nuevo cielo. Si por la quinta vas pasando es mi Cali bella que vas atravesando. Viví ocho años de mi vida en Cali y todavía estoy allá y Cali acá conmigo. Allá conocí el nado sincronizado, que es lo que me va a dar ahora para vivir si no consigo trabajo como antropóloga. Allá me volví deportista y por eso todavía lo puedo seguir siendo; todavía compito en natación representando a la Universidad Nacional de Colombia y por andar de competencia en competencia he dejado de dedicarle tiempo a la tesis. Pero nadar me hace feliz, y de eso también se trata.

Si la locura no me sirve para la antropología, por lo menos me ha servido a veces para vivir mejor. Y, sobre todo, me ha servido para intentar sacar a mi hermano de ella; para poder hablarle en términos que me entendiera, para poder entender su sufrimiento e intentar calmarlo. Leonardo siempre va a ser mi hermano menor y yo siempre lo voy a cuidar y a defender, como cuando éramos niños. 


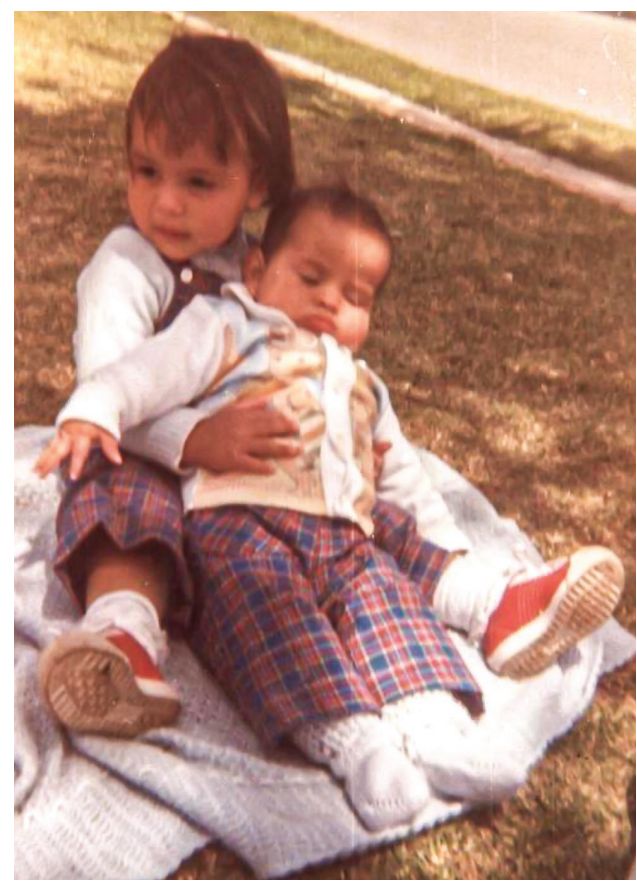

Foto 25. Mi hermano y yo. 1980.

Siamo tutti uguali. Somos todos hermanos. Todos tenemos hambre.

Todos somos máquinas. Todos llegan y se van y pasan por mis ojos, así como yo he pasado por los de muchos otros; muchos me habrán analizado, habrán pensado cosas de mí. A muchos también les he caído mal. Ellos también están acá conmigo.

También las telenovelas han estado conmigo. A veces las veo y hasta lloro porque por fin se descubrió que la protagonista no era la asesina y finalmente su hija supo que ella era la mamá, después de 15 años. Lloro, acompañada de mi mamá, la doctora Aminta Pérez, graduada de medicina de la Universidad Nacional de Colombia, donde -como ella misma decía hace mucho tiempo cuando yo era pequeña y pasábamos por allá- "huele a ciencia". También por estarme viendo esa novela dejé muchas veces de escribir la tesis. Pasó mucho tiempo, tanto que ya no es tesis.

Mi mamá me hacía las tareas del colegio, y también algunas de la universidad; me las hizo hasta que se fue a vivir a Medellín. Ella decía que hacer las tareas no era tan importante. Hay otras cosas importantes que me enseñó mi mamá desde siempre sin decirme nada. Cosas que me hacían no tener miedo del tunecino que en Regina Pacis mientras yo 
servía la comida, casi me pega porque quería tres duraznos y la ración eran dos. Él venía de la cárcel; estaba ahí porque estaba bajo arresto domiciliario y no tenía domicilio en Italia sino en Túnez. Todos hacían lo que él quería. Pero yo no le di el durazno y él me tiró la bandeja de comida en la cara mientras me insultaba en su idioma que yo no entendía, pero sí.

Mi mamá siempre ha escrito conmigo, siempre ha estado ahí; en mis gestos, en mis rasgos, en mi frente grande, "esta niña es igualita a la mamá". Es que yo también soy ella. A ella le di este escrito para que me lo revisara; siempre le he creído todo lo que dice porque ella lo sabe todo.

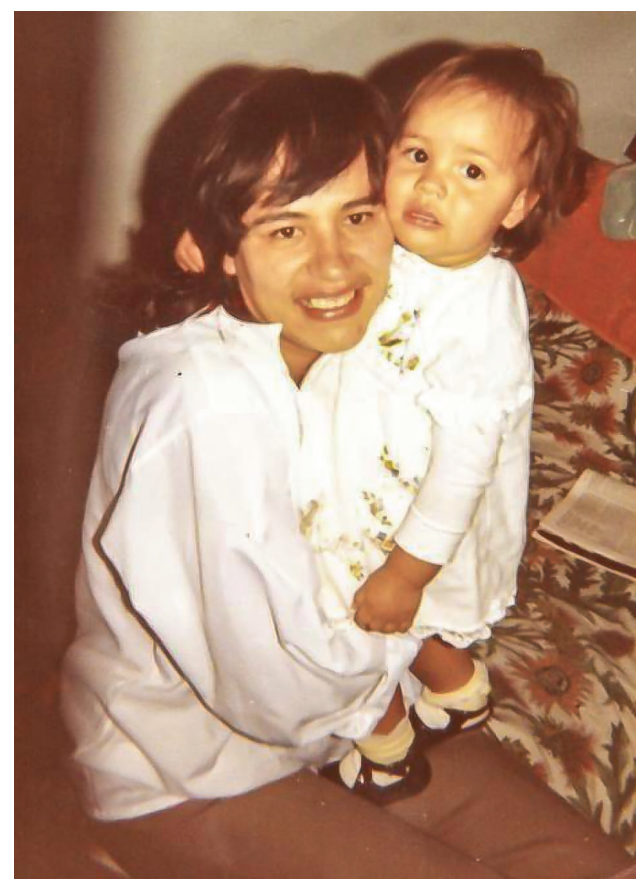

Foto 26. Mi mamá y yo. 1980.

\section{La manera como termino}

La manera en que termino es la misma como empiezo. Las conclusiones están desde el comienzo. Pero si tengo que decir cosas concluyentes con respecto a lo que he escrito, entonces este es el espacio.

Aunque suene obvio, la antropología, como cualquier cosa que uno estudie, debe servir para algo; debe servir a alguien. Puede sonar mesiánico e infantil, como todo mi trabajo, pero creo que la antropología puede servir para vivir mejor. Sin embargo, la pretensión de ser todos 
iguales y felices no tiene sentido para mí. No pretendo elaborar teorías antropológicas ni mucho menos establecer las normas sobre cómo se debe vivir. Ahora, después de sentir en mi propio ser las aceleradas dinámicas humanas que harán que algún día sea extraño hablar de las razas, siento mi pasividad ante el mundo como el mejor indicio de que estoy haciendo algo. Lo que yo decidí mientras estaba en el centro de refugiados fue, como dije antes, vivir, compartir mi vida con ellos. Eso era lo que yo hacía: aprender olvidando, disfrutar sufriendo, llorar riendo. Vivir muriendo. Ahora que lo escribo, lo hago sin muchas pretensiones, con la tranquilidad de lo vivido, de lo sufrido, de lo llorado. Con la certeza de la inmediatez de mi presente, de la inmediatez de lo eterno y la eternidad de lo inmediato; escribo sin miedo a olvidar mientras recuerdo que todo es un eterno olvido. No pretendo que todos mis "datos" sean creídos fielmente; esto es una etnografía de mí misma y soy consciente del grado de subjetividad que hay en ellos. Pretendí a veces abordar esta propia subjetividad, pero ¿desde dónde? El único punto válido para mí desde el que se puede abordar la antropología es sí mismo; el yo que es todos y ninguno, que es el todo y por eso mismo es la nada. Eso, el todo y la nada, fui yo en ese momento, esa soy yo ahora. Mis ojos ya no eran cafés, eran amarillos como los de 林麟 (Lin Lin), y todos los amarillos a los que les decían "China", aunque fueran de Afganistán; mis ojos eran rojos, verdes, eran negros como el negro de Bakarí, que era café, no negro. Eran blancos como el de Петрова (Petrova), la rusa a la que no le gustaba el sol. Yo también era extraña para ellos; para ellos yo era "el otro". 慈恩曹化 (Cí>ēn Cáo Huà), casi se vomita del asco cuando yo me chupaba los dedos mientras comía naranja; ¿cómo era posible que hubiera gente con esas costumbres tan repugnantes? El voluntario italiano veía con curiosidad el hecho de que siempre me pusiera pantalones de cuadros; "es que son los únicos que me quedan buenos después de haberme engordado 15 kilos". Todos ellos también me leían. Y todos ellos ahora, en el año 2005, escriben conmigo; ahora, mientras la tierra sigue girando, mientras estarán llegando más desembarcos desde Albania a las costas italianas, mientras otros estén ganando muchos "dollars" en algún país de Europa Occidental, mientras los niños de Kosovo estén pidiendo limosna en las calles italianas. Todos ellos, y los que ahora leen, están escribiendo conmigo, pero es un requisito que estas líneas sean evaluadas y calificadas - con un número del 0 al 5 , de un sistema numérico de entre tantos posibles- para el código 472281 de la carrera de Antropología de la Universidad Nacional de Colombia. 